

Turkish Studies

\title{
Kovid-19 Salgınının Ekonomi Üzerindeki Etkileri: Türkiye'de İşletme Sahipleri Üzerinde Bir Araştırma
}

\author{
Impact of the Covid-19 Outbreak on the Economy: A Research Study on Business Owners in \\ Turkey
}

\author{
Aslıhan Nakiboğlu* - Sevgül Işık ${ }^{* *}$
}

\begin{abstract}
This research study is conducted using the descriptive survey model in order to determine the opinions of business owners in Turkey on the impacts of the Covid-19 pandemic on the economy. The survey questionnaire form created by the researchers in line with the objective is determined by a random sampling method and applied to the owners of 894 small and medium-sized enterprises (SMEs) who voluntarily accepted to participate in the study over the period between 10 - 17 June 2020. The permit of the Ethics Committee regarding the applicability of the surveys was applied in accordance with the decision of Niğde Ömer Halisdemir University dated 09/06/2020-23012. The obtained data are analyzed via computer software. The frequency and percentage analyses are utilized in determining the descriptive (age, gender, etc.) characteristics of the business owners participating in the survey, whereas the mean and standard deviation statistics are used to examine their opinions regarding the impacts of the Covid-19 outbreak on the economy. T-test, One-way ANOVA test, and Complementary Scheffe test are performed to examine the opinions of business owners regarding the impacts of the Covid-19 outbreak on the economy according to their descriptive characteristics. As a result of the research, it is observed that the business owners have quite negative opinions about the impacts of the Covid-19 pandemic on the economy, and especially they agreed with the expressions "I Think Economic Incentives Are Insufficient", "I Think Small Businesses Face the Risk of Closing" and "I Think Unemployment Will Increase". The opinions of business owners do not differ depending on the legal status of their businesses and whether or not they are family-based businesses, but it is found that female business owners, those with a monthly income of $5000 \mathrm{TL}$ and lower, an annual turnover of less than 100,000 TL, undergraduate education level and those with 15 years or less of activity have more negative opinions regarding the effects of the Covid-19 outbreak on the economy.
\end{abstract}

Structured Abstract: Covid-19 has been seen for the first time in Turkey on March 11, 2020, and the first case of death took place on March 18. Following the first Covid-19 related infection case, firstly the school closures have been mandated by the government in Turkey, borders have been taken under control to limit

\footnotetext{
${ }^{*}$ Doç.Dr. Niğde Ömer Halisdemir Üniversitesi İktisadi ve İdari Bilimler Fakültesi, İktisat Tarihi Assoc.Prof.Dr. Niğde Ömer Halisdemir University, Faculty of Economics and Administrative Sciences, History of Economics

ORCID 0000-0002-6825-984X

anakiboglu@hotmail.com

*** Yüksek Lisans Öğrencisi Niğde Ömer Halisdemir Üniversitesi Sosyal Bilimler Enstitüsü, İktisat Bölümü

Master's Student, Niğde Ömer Halisdemir University Institute of Social Sciences, Department of Economics

ORCID 0000-0001-8314-4760

sevgulll@gmail.com

Cite as/ Atıf: Nakiboğlu, A, Işık, S. (2020). Kovid-19 salgınının ekonomi üzerindeki etkileri: Türkiye'de işletme sahipleri üzerinde bir araştırma. Turkish Studies, 15(4), 765-789. https://dx.doi.org/10.7827/TurkishStudies.43368

Received/Geliş: 04 May/Mayıs 2020

Accepted/Kabul: 10 August/Ağustos 2020

Copyright $\mathbb{C}$ MDE, Turkey

Checked by plagiarism software

Published/Yayın: 30 August/Ağustos 2020

CC BY-NC 4.0
} 
entry/exit, then the citizens arriving from abroad have been kept in compulsory quarantine for 14 days. After that, a curfew has been imposed on the citizen over the age of 65, and the business activities (mainly hairdressers, restaurants, cafes, etc.) have been suspended until further notice.

With the Covid-19 outbreak, the limitation of people's occupational and social lives had negative effects on the economy. This outbreak, which developed at an unexpected moment, caught most businesses unprepared, and the rate of spread of the pandemic and the uncertainty caused by the health anxiety of the individuals to the economic dimension, caused them to experience serious economic and social distress, and as this process continues, the mentioned economic and social concerns are predicted to accelerate.

In this study, it is aimed to determine the views of employers as business owners about the effects of the Covid-19 outbreak on the economy. It is thought that by putting forward the opinions of the employers, it would be possible to determine what the economic concerns and issues they experience are and give an idea for the economic policies that can be implemented to eliminate these concerns.

It is hoped that the performed analyses of the Covid-19 outbreak, its impacts on the economy, and the extent to which those impacts caused economic distress for business owners in Turkey would serve as a reference to future studies to be conducted.

\section{Methodology}

Research Model: This research study is conducted using the descriptive survey model in order to determine the opinions of business owners in Turkey on the impacts of the Covid-19 pandemic on the economy.

Population and its Sample: The population of the research study is comprised of small and mediumsized enterprises (SMEs) operating in Turkey as of 2020. According to data from June 2019, there are 1, 839,000 SMEs operating in Turkey (TEPAV, 2019: 14). The sample of the study, on the other hand, consists of 894 business owners who voluntarily accepted to participate in the survey. The surveys were conducted between 10-17 June 2020. The permit of the Ethics Committee regarding the applicability of the surveys was applied in accordance with the decision of Niğde Ömer Halisdemir University dated 09/06/2020-23012.

Data Collection Tools: The data in the study are collected with a survey questionnaire form prepared by the researchers. The questionnaire form consists of two parts. In the first part, there are 8 multiple choice questions regarding the descriptive characteristics of the participants (age, gender, etc.). In the second part, there is a 5-point Likert type scale with 24 propositions about the effects of the Covid-19 outbreak on the economy.

Statistical Analysis of the Data: The obtained data in the study are analyzed using the SPSS (Statistical Package for Social Sciences) for Windows 22.0 computer software. The frequency and percentage analyses are utilized in determining the descriptive (age, gender, etc.) characteristics of the business owners participating in the survey, whereas the mean and standard deviation statistics are used to examine their opinions regarding the impacts of the Covid-19 outbreak on the economy. T-test, One-way ANOVA test, and Complementary Scheffe test are performed to examine the opinions of business owners regarding the impacts of the Covid-19 outbreak on the economy according to their descriptive characteristics.

\section{Research Findings and Results}

In the research study, the opinions of the business owners are considered in three dimensions such as "The Impacts of Covid-19 on the Sustainability of Economic Activities", "Opinions on Economic Policies Implemented during the Covid-19 Process", "Economic Predictions for the Post-Covid-19 period", and also in another dimension, namely "The Overall Impacts of the Covid-19 Outbreak on the Economy", which expresses the sum of these three dimensions. The participation of the business owners in all dimensions of the scale is high. In other words, considering the negative expressions included in the dimensions of the scale, business owners are seriously worried about their ability to maintain their economic activities during the Covid-19 pandemic, and they consider the economic policies to be implemented in this process as insufficient. Moreover, they also have important concerns in terms of the economy after the Covid-19 outbreak.

The prominent opinions of business owners are as follows: "I Think Economic Incentives Provided Are Insufficient", "I Think Small Businesses are at Risk of Closing Down" and "I Think Unemployment Will Increase". As can be seen from the opinions, business owners think that economic incentives are insufficient, they anticipate that many small businesses will close and unemployment will increase after Covid-19.

Turkish Studies, 15(4) 
In the study, it is also examined whether or not the opinions of business owners about the impacts of the Covid-19 outbreak on the economy differ according to their descriptive characteristics. As the first variable handled in this direction, it is determined that the opinions of the participants on the impacts of the Covid-19 pandemic on the economy differ according to their ages, and participants aged between 20-30 tend to express more negative opinions than those of older age. It is thought that the younger participants who are less likely to experience economic hardships and such crisis situations may be effective in such opinions.

It is determined that there are differences in the opinions of the participants regarding the impacts of the Covid-19 pandemic on the economy according to their gender, and those female business owners in all dimensions tend to express more negative thoughts than males.

Another differentiation is seen in the activity durations of the participants. It is determined that business owners who have been operating for more than 16 years have more positive opinions on the impacts of the Covid-19 outbreak on the economy than those with less operating time.

In the study, it is detected that the legal status of the business owners and the status of family-based businesses do not cause differentiation in their opinions regarding the impacts of the Covid-19 pandemic on the economy.

It is determined that the opinions of the business owners participating in the study regarding the impacts of the Covid-19 outbreak on the economy differ according to their education levels. It is determined that business owners who acquire undergraduate degrees have more negative opinions than business owners with other educational levels.

It is determined that the opinions of the participants regarding the impacts of the Covid-19 outbreak on the economy differ according to their monthly income levels. It is detected that those with a monthly income of $5000 \mathrm{TL}$ or lower have more negative opinions regarding the impacts of the Covid-19 pandemic on the economy than those with higher incomes. In other words, those with low-income levels have more economic concerns. A similar result reveals that there are differences in the opinions of business owners regarding the impacts of the Covid-19 outbreak on the economy, according to their annual turnover. It is concluded that those with an annual turnover of 100,000 TL or lower have more negative opinions regarding the impacts of the Covid-19 pandemic on the economy than the business owners with higher annual turnover, in other words, their economic concerns are more intense.

Keywords: Economisc, Coronavirus, Covid-19, Pandemic, Economic Uncertainty

Öz: Bu araştırma Türkiye' deki işletme sahiplerinin Kovid-19 salgının ekonomi üzerindeki etkilerine yönelik görüşlerini belirlemek amacıyla betimsel tarama modelinde gerçekleştirilmiştir. Amaç doğrultusunda araştırmacılar tarafindan oluşturulan anket formu 10-17 Haziran tarihleri arasında tesadüfi örnekleme yöntemi ile belirlenmiş araştırmaya katılmayı gönüllü kabul eden 894 küçük ve orta boy işletme (KOBİ) sahibine Niğde Ömer Halisdemir Üniversitesi 09/06/2020-23012 tarih ve sayılı etik kurul kararı doğrultusunda uygulanmıştır. Elde edilen veriler bilgisayar ortamında analiz edilmiştir. Araştırmaya katılan işletme sahiplerinin tanımlayıcı (yaş, cinsiyet, vb.) özelliklerinin belirlenmesinde frekans ve yüzde analizlerinden, Kovid-19 Salgınının Ekonomi Üzerinde Etkileri ölçeğine yönelik görüşlerinin incelenmesinde ortalama ve standart sapma istatistiklerinden faydalanılmıştır. İşletme sahiplerinin tanımlayıcı özelliklerine göre Kovid-19 Salgınının Ekonomi Üzerinde Etkilerine yönelik görüşlerinin incelenmesinde ise t-testi, tek yönlü Anova testi ve tamamlayıcı Scheffe testi kullanılmıştır. Araştırma sonucunda işletme sahiplerinin Kovid-19 salgınının ekonomi üzerinde etkilerine yönelik oldukça olumsuz görüşler içerisinde oldukları, özellikle "Verilen Ekonomik Teşviklerin Yetersiz Kaldığını Düşünüyorum”, "Küçük İşletmelerin Kapanma Riskiyle Karşı Karşıya Olduğunu Düşünüyorum” ve “İşsizliğin Artacağını Düşünüyorum” ifadelerine çok yüksek düzeyde katıldıkları görülmüştür. İşletme sahiplerinin görüşlerinin işletmelerinin hukuki statüsüne ve aile işletmesi olup olmamasına göre farklılık göstermediği, ancak kadın işletme sahiplerinin, aylık geliri $5000 \mathrm{TL}$ ve altında, yıllık cirosu 100.000 TL'nin altında bulunan, lisans eğitim düzeyindekilerin ve 15 yıl ve altında faaliyet süresine sahip olanların Kovid-19 salgınının ekonomi üzerinde etkilerine yönelik görüşlerinin daha olumsuz olduğu saptanmıştır.

Anahtar Kelimeler: İktisat, Koronavirüs, Kovid-19, Pandemi, Ekonomik Belirsizlik 


\section{Giriş}

Dünya Sağlık Örgütü, 2020 yılının ilk günlerinde, dünyanın potansiyel pandemi ajanı olan yeni bir koronavirüs ile karşı karşıya olduğunu bildirmiştir (Buruk ve Özlü, 2020: 1) Kovid-19 olarak adlandırılan yeni tip koronavirüs ilk olarak 2019 y1l sonuna doğru Çin'in Wuhan eyaletinde ortaya çıkmış, hızlı bir şekilde yayılarak 2020 yılı Nisan ayı başlarında dünyanın 212 ülkesinde kendini göstermiştir. Çin'de kontrol altına alındığı belirtilen Kovid-19 bulaştığ 1 diğer ülkelerde kontrol altına alınamadığı gibi etkisi hergeçen gün artış kaydetmekte ve diğer ülkelere de yayılmaya devam etmektedir.

Kovid-19'un bulaştığı ülkeler, virüsün bulaşıcılığının hızını azaltmak ve virüsle başa çıkmak için sosyo-ekonomik açıdan yoğun bir çaba sarfetmektedirler. Kovid-19'un bulaşıc1 etkisini önlemek için ülkeler öncelikle sınırlarından giriş ve çıkışları kontrol altına almaya yönelik uygulamalara başlamışlar, vatandaşlarına mecbur kalmadıkça dışarıya çıkmamaları ve sosyal mesafeyi koruyarak, maskesiz dolaşmamalarını önermişlerdir. Ancak alınan tedbirler yetersiz kalıp, virüs yayılmaya devam ettikçe sokağa çıkma yasağı, karantina gibi daha sıkı tedbir ve önlemler alınmaya başlanmıştır.

Kovid-19 Türkiye'de ilk kez 11 Mart 2020 tarihinde görülmüș ve ilk ölüm 18 Mart'ta gerçekleşmiştir. Kovid-19'la ilgili ilk vakanın görülmesinin ardından ilk etapta Türkiye'de okullar tatil edilmiş, sınırlar kontrol altına alınarak giriş-çıkışlar sınırlandırılmış, yurtdışından gelenlere evde 14 gün karantinada kalmaları zorunlu hale getirilmiştir. Ardından 65 yaş üstüne sokağa çıkma yasağı getirilmiş, başta kuaförler, lokantalar, kafeler vb. işletmelerin faaliyetleri durdurulmuştur.

Kovid-19 salgınıyla birlikte insanların iş ve sosyal yaşamlarının sınırlandırılması ekonomi üzerinde olumsuz etkiler göstermiştir. Beklenmeyen bir anda gelişen bu salgın hastalık çoğu işletmenin hazırlıksız yakalanmasına ve salgının yayılma hızı ve yol açtığı belirsizlik bireylerin sağlık açısından duyduğu endişeyi ekonomik boyuta taşımış, ciddi ekonomik ve sosyal kaygılar yaşamalarına neden olmuş ve bu süreç devam ettikçe sözü edilen ekonomik ve sosyal kaygıların daha da hız kazanacağı öngörülmektedir.

Bu çalışmada Kovid-19 salgınının ekonomi üzerindeki etkilerine yönelik işletme sahipleri olarak işverenlerin görüşlerinin belirlenmesi amaçlanmıştır. İşverenlerin görüşlerinin ortaya konulmasıyla, yaşadıkları ekonomik endişelerin ve konuların neler olduğu belirlenebilecek ve bu endişelerin giderilmesine yönelik uygulanabilecek ekonomi politikaları için fikir vereceği düşünülmektedir.

Araştırmada Kovid-19'un ortaya çıkışı ve ekonomiye etkileri analiz edilerek salgının Türkiye'deki işletme sahipleri üzerinde nasıl bir ekonomik sıkıntı yarattığı hakkında ileriki çalışmalara referans bir bilgi kaynağı olması ümit edilmektedir.

\section{Kovid-19 Salgını ve Ekonomiye Etkileri}

İnsanoğlu yüzlerce yıldır hastalıklarla hem mücadele etmiş, insan kayıpları yaşamış ve iktisadi zararlara katlanmak zorunda kalmıştır. Hele de böylesi salgınlara hazırlıksız ve faaliyet planı yapılmamışsa salgın hastalıklar "toplum düzeyindeki etkisi virüsün bulaştırıcılığına, hastalık oluşturma durumuna, bireylerdeki bağışıklık durumuna, bireylerarası temas ve toplumlararası ulaşım özelliklerine, risk faktörü varlıklarına, sunulan sağlı hizmetlerine, iklimine bağlı olarak değişiklikler göstermektedir. Salgın hastalıklar devlet ve toplum için yaşamsal öneme sahip faaliyetleri ve toplum yaşamındaki olağan akışın önemli ölçüde etkileyerek, çeşitli zorluklara ve iktisadi kayıplara sebep olmaktadır.” (T.C. Sağlı Bakanlığı, 2019: 2).

Araştırmanın bu bölümünde öncelikle Kovid-19 salgınının ortaya çıkması ve yayılması açıklanarak, Türkiye'nin Kovid-19 salgınıyla mücadelesine yer verilmiş, Kovid-19 salgınına karş1 
dünya ülkelerinin ekonomik paketleriyle birlikte Türkiye'nin ekonomik paket içeriğinden bahsedilmiş ve Kovid-19 salgınının ekonomi üzerindeki etkilerine yer verilmiştir.

\section{Kovid -19 Salgınının Ortaya Çıkması ve Yayılması}

Dünya ülkelerinin koronavirüsle ilk kez tanışmaları Kovid-19'la olmamıştır. 2002 yılı Kasım ayında Çin'de ortaya çıkan, Uzakdoğu ülkelerinde milyonlarca kişiyi etkileyerek ölümlere yol açan, yabani kedilerden bulaştığı belirlenen "Şiddetli Akut Solunum Sendromu" SARS ve 2012 yılında Suudi Arabistan ve diğer Ortadoğu ülkelerinde birçok kişinin ölümüne yol açan ve develerden yayıldığı düşünülen "Orta Doğu Solunum Sendromu" (MERS) koronavirüs ailesindendir. \%10 ölüm oranına sahip olan SARS 8000 kişiyi etkilemiş ve 800'e yakın kişinin ölümüne yol açmıştır. MERS ise \%30 ile çok daha yüksek ölüm oranına sahiptir (Karcıŏlu, 2020: 66). "Yeni koronavirüs, daha önce insanlarda tanımlanmamıştır. Bu yeni virüs, soğuk algınlığı, SARS ve MERS gibi virüsleri de içeren bir virüs ailesi olan koronavirüs olup geçici olarak 2019-nCoV. olarak adlandırılmıştır. 12 Şubat 2020 itibariyle Kovid-19 olarak güncellenmiştir” (T.C. Sağlık Bakanlığı Kovid-19 Rehberi, 2020).

Koronavirüs ailesinin yeni üyesi Kovid-19 ilk olarak 2019 yılı Aralık ayı sonlarına doğru Çin'in Wuhan eyaletinde görülmüşsür. Yarasa kökenli olduğu düşünülmektedir. Yüksek ateş, takip eden kuru öksürük, yorgunluk, balgam üretimi, solunum güçlüğü, boğaz, baş, kas ve eklem ağrıları en sık görülen hastalık belirtileridir. Yaptığı hastalık başlangıçta ölümcül olmayan bir pnömoni olarak tanımlanırken günümüzde \%3.4 ölüm oranına sahip Kovid-19 hastalığı olarak nitelendirilmektedir. Kovid-19 Dünya Sağllk Örgütü (DSÖ) verilerine göre 2020 y1lı Nisan ay1 başlarında 212 ülkeye yayılmış ve 1.434 .235 kişiye bulaşarak 82.143 kişinin ölümüne neden olmuştur (Buruk ve Özlü, 2020: 1).

Tedavisinde çeşitli ilaçlar denenmesine karşın henüz onaylı tedavi bulunmamaktadır. Aşı geliştirme çalışmaları ve virüsün yok edilmesine ilişkin ilaç çalışmaları Türkiye'de ve diğer ülkelerde sürmektedir. Şu an için Kovid-19'la mücadelede en etkin yol, kişisel temastan uzak durma, bağışıklık sisteminin güçlendirilmesi ve doğru hijyen davranışları geliştirmektir.

\section{Türkiye'nin Kovid 19 Salgınıyla Mücadelesi}

Türkiye'nin Kovid-19'la mücadele süreci vakanın görüldüğü 11 Mart 2020 tarihinden önce başlamıştır. Çin'de ortaya çıkması ve ardından özellikle komşusu olsn İran'da hızlı yayılma sürecine girmesi Türkiye'yi bir dizi önlemler almaya yöneltmiştir. İlk olarak Sağlık Bakanlığı bünyesinde Kovid-19 ile ilgili kararlar almak için 35 uzman kişiden oluşan bilim kurulu oluşturulmuştur. Ardından 22 Ocak 2020'de Wuhan'dan İstanbul'a yapılan uçuşlar durdurulmuştur. Çin'den Türkiye'ye yapılan tüm uçuşların durdurulması ise 22 Şubat'a kadar sürmüştür. 19 Şubat'ta İran'da ilk Kovid-19 vakasının görülmeye başlamasından dört gün sonra 23 Şubat'ta Türkiye; İran'la kara sınırını kapatmış, tüm uluslararası uçuşları da tek taraflı ve geçici olarak askıya almıştır (Sözcü Gazetesi, 14 Mart, 2020).

11 Mart'ta ilk vakanın görülmesinin ardından hızlı bir yayılma sürecine giren Kovid-19, 7 Nisan tarihinde 222.868 'e ulaşmış durumdadır. Kovid-19 nedeniyle hayatını kaybedenlerin sayısı ise 725'e ulaşmıştır (https://covid19.saglik.gov.tr/)

Kovid-19'la mücadele kapsamında Cumhurbaşkanı Tayyip Erdoğan başkanlığında 12 Mart'ta korona virüsü zirvesi düzenlenmiştir. Zirve sonucunda alınan önlemler kamuoyuyla paylaşıldı. Alınan başlıca önlemler (Yeniçağ Gazetesi 18 Mart 2020) şunlardır:

- İlk ve orta dereceli okullar 2 hafta süreyle, üniversiteler 3 hafta süreyle tatil edildi, arından 23 Mart itibariyle de internet ve uzaktan eğitim sürecine geçildi.

- Spor etkinliklerinin seyircisiz oynanmasına karar verildi. 
- Kamu görevlilerine yurtdışına çıkma yasağı getirildi.

- Özel kreşler ve gündüz bakımevleri 16 Mart'tan itibaren ikinci bir uyarıya kadar tatil edildi, ardından faaliyetleri durduruldu.

- Askerlerin çarşı izinleri iptal edildi.

- Vatandaşların yoğun olduğu noktalara dezenfektanlar yerleştirildi.

- Toplu halde kılınan Cuma namazları iptal edildi. Ardından camilerde cemaatle namaz kılınmaması kararlaştıııldı.

- Tüm belediyelerin sosyal, kültürel ve sanatsal etkinlikleri iptal edildi.

- Devlet kurumlarında çalışan hamileler, süt izni kullananlar, öğrenciler, engelliler ve 60 yaş ve üzerindekiler 16 Mart itibarıyla 12 gün idari izinli sayıldı.

- Fransa, Almanya, Norveç, Danimarka, İsveç, İspanya, Hollanda, Belçika ve Avusturya'ya uçuşlar 17 Nisan'a kadar durduruldu.

İleriki tarihlerde kuaför ve berberlerin faaliyetleri durdurulmuş, kafeteryalar kapatılırken, lokanta ve yiyecek içecek hizmeti veren yerler gel-al ve paket servise geçirilmiştir. Tiyatro, sinema, çocuk alanları vb. insanların toplu halde bulunduğu işletmelerin faaliyetleri durdurularak, 30 büyük şehir ve Zonguldak iline giriş çıkışlar sınırlandırılarak izne tabi tutulmuştur. 65 yaş üstüne getirilen sokağa çıkma yasağının kapsamı 60 yaş üstü ve 20 altı yaş olarak genişletilmiş, marketlerde maskesiz giriş çıkışlar yasaklanarak tedbirler sıkılaştırılmıştır. Alınan ekonomik tedbirler araştırmanın müteakip bölümünde yer almaktadır.

\section{Kovid-19 Salgınına Karşı Dünya Ülkelerinin Ekonomik Paketleri ve Türkiye}

Kovid-19'la mücadele sosyo-ekonomik açıdan tam bir savaşa dönmüştür. Bu savaşı Çin ilk kazanan ülke olarak görülmektedir. Hong Kong, Tayvan, Singapur ve Japonya 2003 y1lındaki SARS salgınından dolayı salgınla mücadelede daha deneyim sahibidirler ve bu nedenle de Kovid-19'un etkileri bu ülkelerde daha sınırlı düzeyde kalmıştır.

Kovid-19'la mücadelede birçok ülke hızlı ve titiz tedbirler alırken, virüsü baskılamak için büyük bir enerji harcamaktadırlar. Ayrıca, kamu politikasının müdahaleleri yoluyla ekonomiyi istikrara kavuşturmak için önemli çaba sarf edilmektedir (Smit vd., 2020).

Geleneksel iktisatçılar, bulaşıcı bir hastalığı yayan bireylerin eylemlerinin bir enfeksiyon riski biçiminde (sadece bireyin doğrudan etkileşimde bulunduğu kişilerle değil, aynı zamanda etkileşimde bulundukları kişiler için) toplum içinde dışsallık oluşturduğunu ve böylece hastalık risklerini artırdığını düşünürler (Reddy, 2020).

Geleneksel iktisadi düşüncenin mevcut durumda çok sınırlı bir rehberlik sunmasının önemli nedenlerden birisi temel belirsizliğin varlığıdır. İktisatçılar uzun süredir belirsizlik ve risk arasında bir ayrım yapmıştır. Belirsizlik, tipik olarak, riskin aksine, doğrudan bir olasılık atanamayan sonuçları içerdiği anlaşılmaktadır. Ekonomi, temel belirsizliklerin varlığında nasıl karar verileceğini anlamak için sınırlı kaynaklar sunar. Ancak daha derin bir belirsizlik biçimi, olası sonuçların kolayca tahmin edilemediği bir durumu ifade etmektedir (Reddy, 2020).

Panik, bir risk faktörüdür ve yanlış kamu eylemleri tarafından tetiklenebilir veya doğru eylemler tarafindan sakinleştirilebilir. Hükümetler, toplam talebi, geniş tabanlı ödeme gücü ve likiditeyi sürdürmek için firmaların ayakta kalmasını, istihdam ve gelirlerin sürekliliğini sağlayan bir geri dönüş sağlayabilir. Bu, ekonomik faaliyetin devam etmesini sağlamak ve geri dönüşü olmayan zararları önlemek için doğrudan sübvansiyonlar ve transferler gerektirebilir. Ancak bunlar, belirsizliği ortadan kaldırmanın değil, onu çözmenin yollarıdır (Reddy, 2020). Bu doğrultuda Kovid19 salgınının görüldüğü ülkeler yaşanan belirsiz ortama yönelik bir dizi önlemler alarak ekonomik 
paketler açıklamışlardır. Salgının görüldüğü dünya genelinde 19 ülkenin karşılaştırılmasının yapıldığı "Hükümetlerin Büyük Sinavr: 19 Ülkede Kovid-19 Destek Paketleri" başlıklı araştırmada ülkelerin destek paketleri incelenmiştir. Çalışma kapsamında değerlendirilen 19 ülkenin tamamı Kovid-19 ile mücadelede bir destek paketi açıklamış olsa da 30 Mart 2020 itibarıla bunlardan 10 'u bu paketin büyüklüğü ile ilgili bilgi paylaşmışlardır (EY, 2020: 10).

Dünya genelinde ülkeler Kovid-19 salgınının getirdiği insani ve ekonomik krizle mücadele için destek paketleri açıklamaktadır. Salgın etkisini ve şiddetini artırdıkça paketlerin boyutu/ kapsamı genişlemektedir. Yüksek gelirli ülkelerin paketlerini Gayrisafi Yurtiçi Hasılalarının (GSYH) \%25'i bandına kadar çıkarttıkları görülmektedir (Şekil 1).

Çin, İtalya, İspanya, ABD ve Almanya gibi Kovid-19 salgınından en erken ve en ağır şekilde etkilenen ülkeler salgının şiddeti ve kapsamı arttıkça destek paketlerini güncellemek, daha büyük ve kapsamlı ek paketlerle genişletmek durumunda kalmışlardır.

Kovid-19 ile mücadelede bir destek paketi açıklayan ülkelere bakıldığında GSYH'ye oranla üç temel eğilim görmek mümkündür. 053 band1, 410 band1, 10 ve üzeri bandı. Mart ayına kadar Kovid-19 salgınının hızına ve etkilerine ilişkin daha iyimser beklentileri olan ABD 27 Mart tarihinde yeni destek ve tedbirlerle Kovid-19 destek paketini 2 Trilyon USD'ye GSYH'sinin yaklaş1k \%10'u kadar genişletmek durumunda kalmıştır. Böylece açıklanan en büyük Kovid 19 destek paketini duyurmuş oldu, Almanya ise 26 Mart tarihli güncel paketi ile GSYH'sinin yaklaşık 22'si 800 Milyar USD'yi Kovid-19'un getirdiği insani ve ekonomik krizin etkilerini ortadan kaldırmak için kullanacağını açıklamıştır. Almanya, 50 Milyon nüfusun üzerindeki ülkeler arasında GSYH'sine oranla en yüksek destek paketini açılayan ülkedir (EY, 2020: 10).

Çin: Kovid-2019 hastalığının ilk kez görüldüğü Çin, IMF verilerine göre virüsle mücadele amacıyla yapılacak mali yardıma yaklaşık 183 milyar dolar ayırdı. Bu paket kapsamında salgın önleme ve kontrollü harcamaların artırılması, tıbbi malzeme üretiminin kapsamının genişletilmesi, işsizlik sigortasının ödenmesine ivme kazandırılması ve vergi indirimleri öngörülmektedir (Kıran, 2020). 


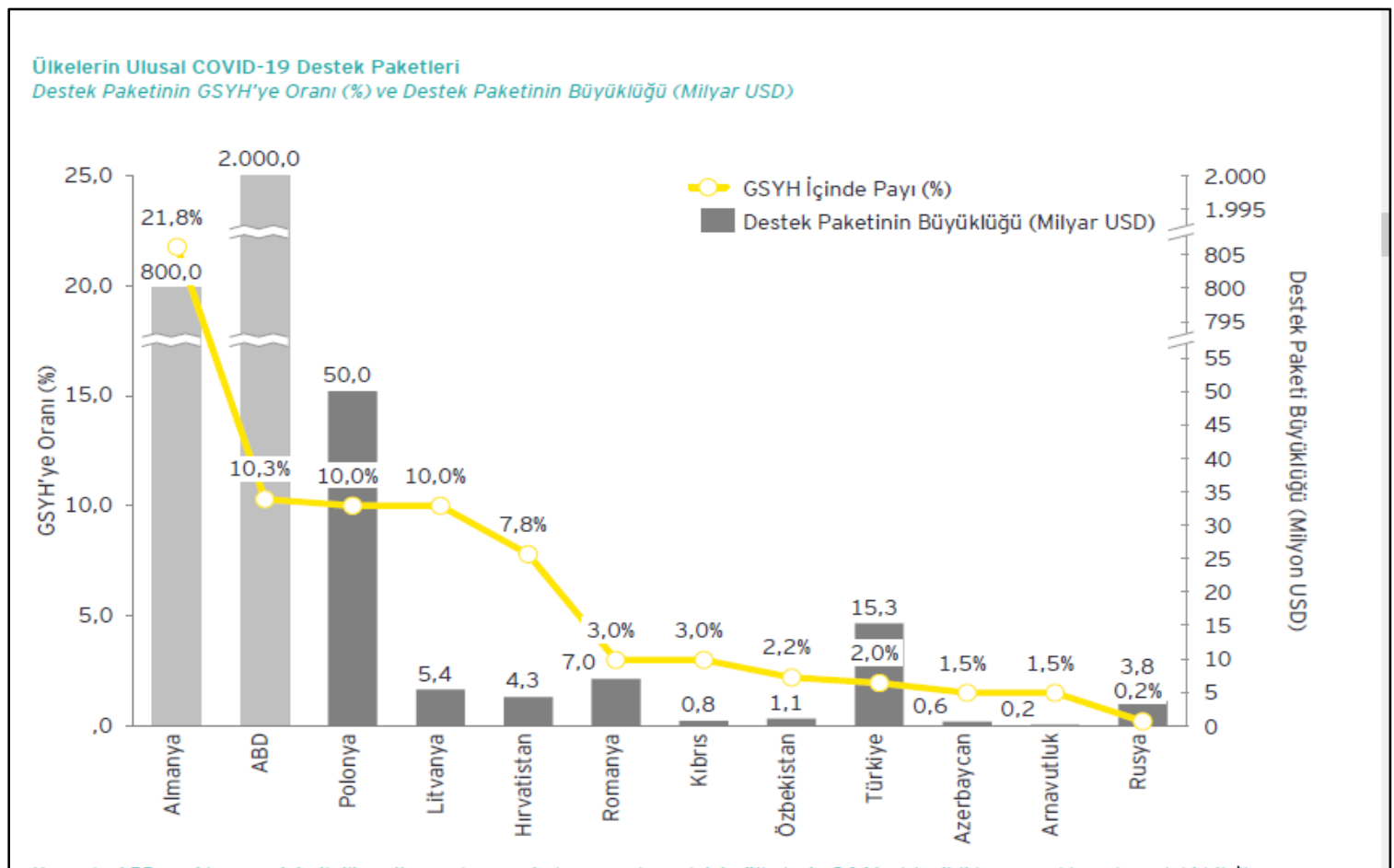

Şekil 1: Kovid-19 Sürecinde Ülkelerin Ulusal Destek Paketlerinin GSYH'ye Oranı (\%)

Kaynak: EY, 2020:10.

Almanya: Almanya 750 milyar euro değerinde bir kurtarma paketini yürürlüğe koymuştur (Kıran, 2020). Almanya'da Kovid-19 salgınından mağduriyetleri önlemek için kısa çalışma ödenekleri yürürlüğe konulmuştur. Ancak planlanan yardımların çoğu kredi yardımını öngördüğü için sıcak parayla yürüyen orta ölçekli pek çok işletme iflasın eşiğine gelmiştir. Bunun üzerine 10 ve üstü çalıșanlı orta ölçekli şirketlere 15 bin euro sıcak para desteği verileceği açıklanmıștır. Almanya büyük şirketlere de iflas durumunda bazı hisselerin devlete devri karşılığında sermaye yardımı yapacağını bildirmiştir. $\mathrm{Bu}$ geçici de olsa şirketlerin kamulaştırılması anlamına gelmektedir (https://www.setav.org/5-soru-almanya-koronavirus-ile-nasil-mucadele-ediyor/).

Fransa: Fransa'da hükümet, toplam 345 milyar euro değerinde bir koronavirüsle mücadele paketi açıklamıştır. 300 milyar euroya kadar şirket kredisi vereceklerini duyuran Fransa, bunun yanı sıra 45 milyar euro da likidite desteğine ayırd. Ayrıca Fransa'da da serbest çalışanlara doğrudan destek önlemleri alınmıştır (Kıran, 2020).

İtalya: Birçok kamu ve özel borç yükümlülüğü (konut kiraları ve faiz ödemeleri gibi) askıya alınmıştır. İtalya, Kovid-2019 salgını bitene kadar ekonomik saati yavaşlatmaya çalışmaktadır (Sinn, 2020). Bu doğrultuda 25 milyar euro değerinde bir önlemler paketi açıklamıştır (Kıran, 2020).

Amerika Birleşik Devletleri: Covid-19 salgının ekonomik ve toplumsal yıkımını yaklaşık 2 trilyon dolar değerindeki yardım paketini yürürlüğe koymuştur. Paket kapsamında, her ABD vatandaşına kişi başı bin 200 dolarlık çek, küçük ölçekli işletmelere hızlı yardım ve holdinglere milyar dolarlık krediler verilmesi öngörülmüştür. Ayrıca 100 milyar dolardan fazla bir yardım sağlık sistemi ve hastanelere, bir diğer 100 milyar dolardan fazla bir dilim de eyalet, kent ve belediyelere aktarılacağı belirtilmiştir (Kıran, 2020).

Türkiye: Virüsün yayılım hızını azaltmak için alınan tedbirlerle birlikte virüs nedeniyle sınırlandırılan ekonomik faaliyetler yüzünden ortaya çıkabilecek gelir kaybı, işsizlik vb. ortaya 
çıkabilecek sorunlara karşı hükümet tarafından önlemler alınmıştır. Ekonomik istikrar kalkanı olarak adlandırılan ekonomik paketle 100 milyar liralık bir kaynak devreye alınmıştır. Paketin içeriği şunlardır (Anadolu Ajansı, 18 Mart 2020):

1. "Perakende, AVM, Demir-Çelik, Otomotiv, Lojistik-Ulaşım, Sinema-Tiyatro, Konaklama, Yiyecek-İçecek, Tekstil-Konfeksiyon ve Etkinlik-Organizayon sektörleri için Muhtasar ve KDV tevkifatı ile SGK primlerinin Nisan, Mayıs ve Haziran ödemelerini 6'şar ay ertelenmiştir.

2. Konaklama vergisini Kasım ayına kadar uygulanmama kararı alınmıştır.

3. Otel kiralamalarına ilişkin irtifak hakkı bedelleri ve hasılat payı ödemeleri Nisan, Mayıs ve Haziran ayları için 6 ay süreyle ertelenmiştir.

4. İç havayolu taşımacılığında 3 ay süreyle KDV oranını yüzde 18 'den yüzde 1'e indirilmiştir.

5. Kovid-19 salgınıyla ilgili tedbirlerden etkilendiği için nakit akışı bozulan firmaların bankalara olan kredi anapara ve faiz ödemelerini asgari 3 ay ötelenmesi ve gerektiğinde bunlara ilave finansman desteği sağlanması kararlaştırılmıştır.

6. İhracattaki geçici yavaşlama sürecinde kapasite kullanım oranlarının korunması amacıyla ihracatçıya stok finansmanı desteği verilmesi kararlaştırılmıştır.

7. $\mathrm{Bu}$ dönemde işlerinin olumsuz etkilendiğini beyan ederek talepte bulunan esnaf ve sanatkârların Halkbank'a olan kredi borçları, Nisan, Mayıs ve Haziran anapara ve faiz ödemeleri 3 ay süreyle ve faizsiz olarak ertelenmiştir.

8. Kredi Garanti Fonu limitini 25 milyar liradan 50 milyar liraya ç1kartarak, kredilerde öncelik, gelişmelerden olumsuz etkilendiği için likidite ihtiyacı oluşan ve teminat açığı bulunan firmalar ile KOBİ'lere verilmiştir.

9. Vatandaşlar için uygun ve avantajlı şartlarda sosyal amaçlı kredi paketleri devreye alınması teşvik edilmiştir.

10. 500 bin liranın altındaki konutlarda kredilendirilebilir miktarı yüzde 80 'den yüzde 90 'a çıkartılmış, asgari peşinat yüzde 10'a düşürülmüştür.

11. Virüsün yayılmasına karşı alınan tedbirlerin etkisiyle Nisan, Mayıs ve Haziran aylarında temerrüte düşen firmaların kredi siciline mücbir sebep notu düşülmesi sağlanmıştır.

12. Stopaj gibi kaynağında yapılan kesintilerin ödemelerini içeren içeren muhtasar beyannamelerin süreleri 3 ay ertelenmiştir.

13. Asgari ücret desteğine devam edilmesi kararlaştırılmıştır.

14. Mevzuattaki esnek ve uzaktan çalışma modelleri daha etkin hale getirilmiştir.

15. Kısa Çalışma Ödeneğini devreye alınmış, bundan faydalanmak için gereken süreçler kolaylaştırılarak, hızlandırılmıştır. Böylece faaliyetine ara veren iş yerlerindeki işçilere geçici bir gelir desteği verilirken, işverenlerin de maliyeti azaltılmıştır.

16. En düşük emekli maaşı 1.500 liraya yükseltilmiştir.

17. Emeklilerin bayram ikramiyesi Nisan ayı başında ödenmiştir. Yine emeklilerin maaş promosyon ödemeleri de şubelere gitmelerine gerek kalmaksızın, doğrudan hesaplarına yatırılmışıtır.

18. Aile, Çalışma ve Sosyal Politikalar Bakanlığının belirlediği kriterlere göre ihtiyaç sahibi ailelere yapılacak nakdi yardımlar için ilave 2 milyar liralık bir kaynak ayrılmıştır.

19. İstihdamdaki sürekliliği temin etmek amacıyla 2 aylık telafi çalışma süresi 4 aya çıkartılmıştır."

Bu süreçte işletmeleri ilgilendiren destekleri; işletmelere yönelik destekler, maliye politikası ve finansman desteği ile para politikası ve likidite destekleri olarak üç alanda verilen destekler şu şekilde özetlenebilir: 
İşletmelere Yönelik Ekonomik Destekler:

- Dezenfektan, maske, eldiven gibi koruyucu ekipmanın yerli üretimini sağlayabilecek KOBİ'lere 6 Milyon TL'ye kadar destek verilecektir.

- İşletmelere kısa çalışma ödeneği sağlanacaktır. Bu sayede iş yapabilme kapasitesinin düştüğü tespit edilen işletmelere çalışan masraflarının (genel sağlık sigortası primleri ve işçilere sağlanacak kısa çalışma ödeneği) kısmi olarak karşılanarak destek verilecektir.

- Yavaşlayan küresel ticaret ortamı nedeniyle ihracatçılara stok desteği verilecektir.

Maliye Politikast ve Finansman Desteği:

- İşletmelere vergi erteleme olanağı tanıyarak muhtasar beyanname süreleri 3 ay süreyle ertelenmiş bulunmaktadır.

- Etkilenen sektörler için verilecek doğrudan destekler kapsamında Türkiye Nisan, Mayıs ve Haziran aylarında temerrüde düşecek firmaların kredi siciline "mücbir sebep" notu düşüleceğini açıklamış, Kovid-19 sebebiyle nakit akışı bozulan firmalara ise ilave finansman desteği garantisi vermiştir.

- İlave olarak KOBİ'lere verilen geri ödemeli destek programlarının ödemeleri 3 ay süreyle ertelemiştir.

\section{Para Politikası ve Likidite Destekleri:}

- Devlet bankaları üzerinden KOBİ'ler başta olmak üzere ödeme sorunu yaşayan müşteriler için ödemesiz dönem uygulamasını hayata geçirmeyi hedeflemektedir.

- Çalışan sayılarında azaltmaya gitmeyen firmaların yararlanabileceği 6 ay ödemesiz düşük faizli kredi programı hayata geçirilmiştir.

- KOBİ'lerin ek finansman ihtiyaçlarında desteklenebilmesi için kredi garanti fonu limiti 25 Milyar TL'den 50 Milyar TL'ye yükseltilmiş, bankaların süreçte yaşayabileceği likidite kısıtlarına karşı bankalara açık piyasa işlemleri çerçevesinde tanınan likidite limitleri artırılmıştır.

- Türkiye Cumhuriyet Merkez Bankası da gelişmelere paralel olarak politika faizinde $100 \mathrm{baz}$ puan indirime gitmiştir.

\section{Kovid-19 Salgınının Ekonomik Etkileri}

Bugün dünyanın ikinci büyük ekonomisi ve dolayısıyla tüm dünya Kovid-19 adı verilen bir virüsün tehdidi altındadır. Virüsün yarattığı belirsizlik, küresel ticaret ve tedarik zincirlerini hızla bozmuş, emtia fiyatlarını düşürmüş ve çokuluslu şirketleri sınırlı bilgilerle kritik kararlar almaya zorlamıştır (Karacaer-Ulusoy, 2020).

Salgının görüldüğü ülkelerde üretim durma noktası gelmiştir. Petrol fiyatları her geçen gün düşüş kaydederken, piyasalarda ve istihdam da daralma, işsizlikte artış beklenmektedir.

Kovid-19 salgınından öncelikli olarak etkilenecek sektörlerin başında seyahat, ulaşım, turizm, konaklama ve perakende sektörleri olacağı tahmin edilmektedir. Turizm sektöründeki daralma, dış talep kaynaklı büyümenin hizmet ayağında ciddi aksamalara neden olacaktır. Seyahat ve konaklama hizmetlerinde yaşanacak azalış ise cari açığın daha da artmasını beraberinde getirecektir.

Ulusal ve uluslararası düzeydeki seyahat hizmetlerine olan arzın Kovid-19'a bağlı olarak ciddi oranda azaldığ 1 ve Kovid-19'un küresel turist hareketliliğini \%1 ile \%3 oranında düşürdügüü, bu durumun uluslararası turizm gelirleri açısından yaklaşık 30 ile 50 milyar dolar kayıp anlamına geldiği belirtilmiştir (UNWTO Impact Assessment of the COVID-19 Outbreak on International Tourism, 2020). 
Kovid-19 salgınının sağlık ürünleri ve gıda sektörüne olumlu katkılar yapacağı değerlendirilmektedir. Mahase (2020) Dünya Sağlık Örgütü (DSÖ) verilerine göre Kovid-19 salgını sürecinde başta maske olmak üzere kişisel koruyucu ekipmanlarda ve solunum cihazlarında talebin 100 kat ve ilgili malzeme fiyatlarının ise yaklaşık 20 kat artış gösterdiğini belirtmektedir.

Kovid-19 salgınının yoğun olduğu ve daha az hissedildiği tüm ülkelerin ekonomisi doğrudan veya dolaylı olarak etkileyecektir. Tüm ülkelerin birbirleriyle olan dış ticaret ilişkileri, virüs nedeniyle alınan tedbirler, sınırlardaki geçişlerdeki güvenlik uygulamaları; mal ve emtiaların dolaşımına olumsuz yansıyacaktır. Üretimin durma noktasına gelmesi enerjiye olan ihtiyacın azalması, tüketimin gıdaya ve sağlığa yönelmesi, turizm, sosyal ve sanatsal etkinliklere yönelik sektörlere yansıması ağır olacaktır. Ayittey, Ayittey, Chiwero, Kamasah ve Dzuvor (2020) araştırmalarında Kovid-19 salgınının Çin ve dünya ekonomisine olan etkilerini araştırmışlardır. Kovid-19'un yılın ilk çeyreğinde Çin ekonomisini yaklaşık 62 milyar dolar ve dünya ekonomisini de 280 milyar doları aşan zarara uğratacağını tahmin etmişlerdir.

Taymaz (2020) Kovid-19 salgınının ekonomik etkilerini incelediği çalışmasında Kovid-19 salgınından doğrudan etkilenen sektörlerin başında konaklama, yiyecek içecek hizmetlerinin geldiğini, en az ise tekstil giyim eşyası ve perakende ticaretinin etkilendiğini varsayarak yaptığı ekonometrik olarak yaptığı analizler sonucunda Kovid-19 tedbirlerinden doğrudan etkilenen sektörlerin çoğu düşük ücretli işçi çalıştıran küçük iş yerlerinden oluştuğunu bundan dolayı da bu sektörlerdeki daralmanın yoksulluğu hızla artıracağını, gelir ve talepteki düşüşün ise hemen hemen tüm sektörlerde ciddi daralmalara yol açacağını belirtmiştir. Bu sorunları hafifletmek için geçici veya süresiz işini kaybeden işçilere acilen kısa çalışma ödeneği ve işsizlik sigortasından (ödeme tavanı arttırılarak) ödeme yapılmasını, emeklilere ve düşük gelirli ailelere ek gelir desteği sağlanması gerekliliğinden bahsederek, bu tedbirlerin özel durumu nedeniyle gelir destekleri, asgari çalışma süresi gibi koşullar konulmadan otomatik olarak uygulanmaya başlanması gerektiğini açıklamıştır.

Kovid-19 salgınının ne zaman biteceği ve dünyanın bu virüsten ne zaman kurtulacağına dair net veriler olmamasından dolayı ekonomiye olabilecek olası etkileri tahminden öteye geçememektedir. Ancak salgının uzaması gerek dünya ekonomisine gerekse ülkelerin ekonomisini ciddi zararlara uğratacak ve uzun süre dünya ekonomisinin eski haline gelemeyeceği düşünülmektedir.

\section{Kovid-19 Salgınının Ekonomi Üzerindeki Etkilerine Yönelik İşletme Sahipleri Üzerinde Bir Araştırma}

\section{Araştırmanın Yöntem ve Modeli}

Araştırma nicel araştırma yöntemlerine göre gerçekleştirilmiştir. Araştırma Türkiye'deki işletme sahiplerinin Kovid-19 salgınının ekonomi üzerindeki etkilerine yönelik görüşlerini belirlemek amacıyla betimsel tarama modelinde yapılmıştır. Tarama modelleri, geçmişte ya da halen var olan bir durumu var olduğu şekilde betimlemeyi amaçlayan araştırma yaklaşımlarıdır (Karasar, 2012:79).

\section{Evren ve Örneklemi}

Araştırmanın evrenini 2020 yılında Türkiye'de faaliyet gösteren küçük ve orta boy işletme (KOBİ) sahipleri oluşturmaktadır. 2019 yılı Haziran ayı verilerine göre Türkiye'de toplam 1 milyon 839 bin KOBİ bulunmaktadır (TEPAV, 2019: 14). Araştırmanın örneklemini ise evren içerisinde bulunan ve tesadüfi örnekleme yöntemi ile belirlenmiş, araştırmaya katılmayı gönüllü kabul eden 894 kişi oluşturmuştur.

Örneklem büyüklüğünün belirlenmesinde örneklem büyüklüğü hesaplama motorundan yararlanılmıştır (https://www.anketcozumu.com). Hesaplamada 1.000.839.000 kişilik evrende $\% 95$ 'lik güven düzeyi, $\alpha=.05$ anlamlılık ve $\% 5$ 'lik hoşgörü düzeyi için gerekli örneklem büyüklüğü

www.turkishstudies.net/turkishstudies 
368 kişi olarak tespit edilmiştir. Araştırma sonuçlarından daha genel verilere ulaşmak için internet ortamında online hazırlanan anket formu sosyal medya aracılığılla ulaşılabilen işletme sahiplerine dağıtılmış ve 894 kullanılabilir anket formuna ulaşılmıştır. Anketler 10-17 Haziran 2020 tarihleri arasında gerçekleştirilmiştir. Anketler; Niğde Ömer Halisdemir Üniversitesi 09/06/2020-23012 tarih ve sayılı kararı etik kurul izin belgesi doğrultusunda uygulanmıştır.

\section{Veri Toplama Araçları}

Araştırmada veriler araştırmacılar tarafindan oluşturulan anket formu ile toplanmıştır. Söz konusu anket formu iki bölümden oluşmaktadır. İlk bölümde katılımcıların tanımlayıcı özelliklerinin (yaş, cinsiyet vb.) belirlenmesine yönelik çoktan seçmeli 8 soru yer almaktadır. İkinci bölümde 5'li likert tipinde Kovid-19 salgınının ekonomi üzerindeki etkilerine yönelik 24 önerme yer almaktadır. Maddeler "(1) Kesinlikle Katılmıyorum ile (5) Kesinlikle Katıliyorum” arasında beşli olarak derecelendirilmiştir. Ölçeklerden elde edilen verilerin değerlendirilmesinde 1,00-1,80 aras düşük, 1,81-2,60 arası düşük, 2,61-3,40 arası orta, 3,41-4,20 aras1 yüksek ve 4,21-5,00 aras1 çok yüksek düzey olarak değerlendirilmiştir. Ölçekte bulunan maddelerin tamamı olumsuz ifadelerden oluşmaktadır. Bundan dolayı da ölçekten alınan yüksek puanlar görüşlerin olumsuzluğuna, düşük puanlar ise olumlu görüşleri ifade etmektedir.

Araştırmada öncelikle Kovid-19 Salgınının Ekonomi Üzerinde Etkileri Ölçeğine geçerlik ve güvenirlik çalışmaları yapılmıştır. Ölçeğin yapı geçerliliğini ortaya koymak için keşfedici faktör analizi yapılmıştır. Yapılan Barlett testi sonucunda faktör analizine alınan değişkenler arasında anlamlı ilişkiler olduğu $(\mathrm{p}=0.000<0.05)$ ve örnek büyüklüğünün faktör analizi uygulanması için yeterli olduğu belirlenmiştir $(\mathrm{KMO}=0.953>0,60)$. Faktör analizi uygulamasında varimax yöntemi seçilerek faktörler arasındaki ilişkinin yapısının aynı kalması sağlanmıştır. Faktör analizi sonucunda değişkenler toplam açıklanan varyansı \%61.789 olan 3 faktör altında toplanmıştır. Faktörlerin içeriklerine bakılarak 10 maddenin yer aldığ 1 ilk faktör 'Kovid-19'un Ekonomik Faaliyetlerin Sürdürülebilirliğine Etkileri" olarak 7 maddenin yer aldığg ikinci faktör "Kovid-19 Sürecinde Uygulanan Ekonomi Politikalarına Yönelik Görüşler" ve 7 maddenin yer aldığı üçüncü faktör "Kovid-19 Sonrasına Yönelik Ekonomik Öngörüler" olarak isimlendirilmiştir. Oluşan faktör yapısı ve faktör yükleri Tablo 1'de görülmektedir.

Tablo 1: Kovid-19 Salgınının Ekonomi Üzerinde Etkileri Ölçeği Faktör Yapısı

\begin{tabular}{lc}
\hline \multicolumn{1}{c}{ Boyut } & $\begin{array}{c}\text { Faktör } \\
\text { Yükü }\end{array}$ \\
\hline Kovid-19'un Ekonomik Faaliyetlerin Sürdürülebilirliğine Etkileri (Özdeğer=12,381; Açılanan & \\
Varyans=22,892) & 0,718 \\
23.İşyerimde Çalışan Sayısını Azaltmak Zorunda Kalacağımı Düşünüyorum & 0,706 \\
20.Çek ve Senetlerimi Ödeyemeyeceğimi Düşünüyorum & 0,700 \\
17.Sunduğumuz Ürün ve Hizmetlere Eskisi Gibi Talep Olmayacağı Kanaatindeyim & 0,665 \\
5.Evime ve Çocuklarıma Bakamamaktan Endişeliyim & 0,651 \\
16.Kredi ve Kredi Kartı Ödemelerinden Dolayı Bankalarla Sıkıntı Yaşayacağımı Düşünüyorum & 0,632 \\
24.Önemli Düzeyde İş Kaybı Yaşayacağımı Düşünüyorum & 0,625 \\
4.İşerimi Kapatmak Zorunda Kalmaktan Korkuyorum & 0,624 \\
21.Yeni Girişimcilik Faaliyetlerine Yönelemeyeceğimi Düşünüyorum & 0,598 \\
7.Alacaklarımı Tahsil Edemeyeceğimi Düşünüyorum & 0,516 \\
22.Uygulanan Ekonomi Politikalarının Virüs Nedeniyle Gördüğüm Zararı Gideremeyeceğini & \\
Düşünüyorum & Kovid-19 Sürecinde Uygulanan Ekonomi Politikalarına Yönelik Görüşler (Özdeğer=1,296; Açıklanan \\
Varyans=22,851) & 0,739 \\
8.Alınan Ekonomik Tedbirleri Yetersiz Buluyorum & 0,691 \\
10.Verilen Ekonomik Teşviklerin Yetersiz Kaldığını Düşünüyorum & 0,689 \\
1.Gelecekle İlgili Ekonomik Endişelerim Var &
\end{tabular}

Turkish Studies, 15(4) 
6.Bu Dönemdeki Ekonomik Durgunluğun Gelecekte Ekonomik Açıdan Sıkıntı Yaratacağını

Düşünüyorum

0,673

2.Ekonomik Açıdan Kendimi Yetersiz Hissediyorum

0,638

3.Ekonominin Bundan Sonra Kolay Kolay Eski Hale Döneceğine İnanmıyorum

0,617

9.Verilen Teşviklerden Yararlanamıyorum

Kovid-19 Sonrasına Yönelik Ekonomik Öngörüler (Özdeğer=1,152; Açıklanan Varyans=16,046)

13.Tüm Sektörlerin Ekonomik Açıdan Olumsuz Etkilendiğini Düşünüyorum

18.Rekabetin Daha Çok Olup Karlılıkların Azalacağını Düşünüyorum

15.Enflasyonun Ciddi Oranda Artacağını Düşünüyorum

0,570

12.Genel Ekonomiden Dijital Ekonomiye Hızlı Bir Geçiş Yaşanacağını Düşünüyorum 0,564

19.Küçük İşletmelerin Kapanma Riskiyle Karş1 Karşıya Olduğunu Düşünüyorum $\quad 0,563$

14.İșsizliğin Artacağını Düşünüyorum $\quad 0,556$

11.Ekonominin Canlanmasının Uzun Süre Alacağını Düşünüyorum $\quad 0,540$

Toplam Varyans $=\% 61.789$

Ölçekteki faktörlerin puanları hesaplanırken faktördeki maddelerin değerleri toplandıktan sonra madde sayısına bölünerek (aritmetik ortalama) faktör puanları elde edilmiştir.

Kovid-19 Salgınının Ekonomi Üzerinde Etkilerini ölçmek için hazırlanan ölçeğin güvenirlik düzeyini belirlemek için iç tutarlılık katsayısı olan "Cronbach Alpha" hesaplanmıştır. Ulaşılan sonuçlar Tablo 2'de sunulmuştur.

Tablo 2: Kovid-19 Salgınının Ekonomi Üzerinde Etkileri Ölçeği Güvenirlik Düzeyi

\begin{tabular}{lll}
\hline Boyut & $\begin{array}{l}\text { Madde } \\
\text { Sayısı }\end{array}$ & $\begin{array}{l}\text { Güvenirlik Değeri } \\
\text { "Cronbach Alpha" }\end{array}$ \\
\hline $\begin{array}{l}\text { Kovid-19'un Ekonomik Faaliyetlerin Sürdürülebilirliğine } \\
\text { Etkileri }\end{array}$ & 10 & 0,926 \\
$\begin{array}{l}\text { Kovid-19 Sürecinde Uygulanan Ekonomi Politikalarına } \\
\text { Yönelik Görüsler }\end{array}$ & 7 & 0,891 \\
Kovid-19 Sonrasına Yönelik Ekonomik Öngörüler & 7 & 0,871 \\
Kovid-19 Salgınının Ekonomi Üzerinde Etkileri (Genel) & 24 & 0.957 \\
\hline
\end{tabular}

Tablo 2'de görüldüğü üzere Kovid-19'un Ekonomik Faaliyetlerin Sürdürülebilirliğine Etkileri boyutunun güvenirlik değeri $\alpha=0,926$, Kovid-19 Sürecinde Uygulanan Ekonomi Politikalarına Yönelik Görüşler boyutunun güvenirlik değeri $\alpha=0,891$, Kovid-19 Sonrasına Yönelik Ekonomik Öngörüler boyutunun güvenirlik değeri $\alpha=0,871$ ve Kovid-19 Salgınının Ekonomi Üzerinde Etkileri ölçeğinin genel güvenirlik düzeyi $\alpha=0,957$ olarak bulunmuştur.

Alpha değerinin 0,81'in üzerinde olmasının ölçeğin yüksek düzeyde güvenilir olduğu belirtilmektedir (Kılıç, 2016: 48). Güvenirliğine ilişkin bulunan alpha ve açıklanan varyans değerine göre Kovid-19 Salgınının Ekonomi Üzerinde Etkileri ölçeğinin geçerli ve güvenilir bir araç olduğu söylenebilir.

\section{Verilerin İstatistiksel Analizi}

Araştırmada elde edilen veriler SPSS (Statistical Package for Social Sciences) for Windows 22.0 programı kullanılarak analiz edilmiştir. Araştırmaya katılan işletme sahiplerinin tanımlayıcı (yaş, cinsiyet, vb.) özelliklerinin belirlenmesinde frekans ve yüzde analizlerinden, Kovid-19 Salgınının Ekonomi Üzerinde Etkileri ölçeğine yönelik görüşlerinin incelenmesinde ortalama ve standart sapma istatistiklerinden faydalanılmıştır. İşletme sahiplerinin tanımlayıcı özelliklerine göre Kovid-19 Salgınının Ekonomi Üzerinde Etkilerine yönelik görüşlerinin incelenmesinde ise t-testi, tek yönlü Anova testi ve tamamlayıcı Scheffe testi kullanılmıştır. 


\section{Araştırmanın Bulguları}

Araştırmaya katılan işletme sahiplerinin tanımlayıcı özelliklerine yönelik veriler Tablo 3'te sunulmuştur.

Tablo 3: Katılımcıların Tanımlayıcı Özellikleri

\begin{tabular}{|c|c|c|c|}
\hline & Gruplar & Frekans(n) & Yüzde (\%) \\
\hline \multirow[t]{4}{*}{ Yaş } & $20-30$ & 66 & 7,4 \\
\hline & $31-40$ & 360 & 40,3 \\
\hline & $41-50$ & 366 & 40,9 \\
\hline & $51-60$ & 102 & 11,4 \\
\hline \multirow[t]{2}{*}{ Cinsiyet } & Kadın & 204 & 22,8 \\
\hline & Erkek & 690 & 77,2 \\
\hline \multirow[t]{5}{*}{ Faaliyet Yılı } & $1-5$ Yil & 156 & 17,4 \\
\hline & $6-10$ Yil & 231 & 25,8 \\
\hline & $11-15 Y_{11}$ & 177 & 19,8 \\
\hline & $16-20 Y_{11}$ & 177 & 19,8 \\
\hline & 21 Y1l ve Üzeri & 153 & 17,1 \\
\hline \multirow{4}{*}{ İşletmenin Hukuki Statüsü } & Şahıs İşletmesi & 426 & 47,7 \\
\hline & Anonim Şirket & 42 & 4,7 \\
\hline & Limited Şirket & 390 & 43,6 \\
\hline & Diğer & 36 & 4,0 \\
\hline \multirow[t]{2}{*}{ İşletmenin Aile İşletmesi Olma Durumu } & Evet & 375 & 41,9 \\
\hline & Hayır & 519 & 58,1 \\
\hline \multirow[t]{4}{*}{ Eğitim Düzeyi } & Lise ve Alt1 & 327 & 36,6 \\
\hline & Önlisans & 84 & 9,4 \\
\hline & Lisans & 369 & 41,3 \\
\hline & Lisansüstü & 114 & 12,8 \\
\hline \multirow[t]{7}{*}{ Aylık Gelir Düzeyi } & 5000 TL ve Alt1 & 249 & 27,9 \\
\hline & $5001-10000 \mathrm{TL}$ & 300 & 33,6 \\
\hline & $10001-15000 \mathrm{TL}$ & 195 & 21,8 \\
\hline & $15001-2000 \mathrm{TL}$ & 84 & 9,4 \\
\hline & 20001 TL ve Üzeri & 66 & 7,4 \\
\hline & 100.000 TL ve Alt1 & 183 & 20,5 \\
\hline & $100 . .000-250.000 \mathrm{TL}$ & 129 & 14,4 \\
\hline \multirow{4}{*}{ İşletme Cirosu (Yıllık) } & $251 . .000-500.000 \mathrm{TL}$ & 90 & 10,1 \\
\hline & $501 . .000-750.000 \mathrm{TL}$ & 48 & 5,4 \\
\hline & $751 . .000-1000.000 \mathrm{TL}$ & 108 & 12,1 \\
\hline & 1001.000 TL ve Üzeri & 336 & 37,6 \\
\hline
\end{tabular}

Tablo 3'teki veriler incelendiğinde araştırmaya katılan işletme çalışanlarının 66'sı $(\% 7,4) 20$ 30, 360'1 (\%40,3) 31-40, 366's1 (\%40,9) 41-50, 102'si (\%11,4) 51-60 yaşlarında bulunmaktadır. Katılımciların 204'ü $(\% 22,8)$ kadın, 690'1 $(\% 77,2)$ erkek olup, 156's1 $(\% 17,4)$ 1-5 y1l arasında 231'i (\%25,8) 6-10 y1l arasında, 177'si (\%19,8) 11-15 y1l arasında 177'si $(\% 19,8) 16-20$ y1l arasinda ve 153 'ü $(\% 17,1) 21$ yıl ve üzeri işletmeleri faaliyet göstermektedir. Katılımcıların 426'sının işletmesi $(\% 47,7)$ şahıs işletmesi, 42 'sinin $(\% 4,7)$ anonim şirket, 390'ının $(\% 43,6)$ limited şirket ve 36'sının $(\% 4,0)$ diğer statülerde olup, 375'inin işletmesi $(\% 41,9)$ aile işletmesidir.

Araştırmaya katılan işletme sahiplerinin 327'si $(\% 36,6)$ lise ve altı, 84'ü $(\% 9,4)$ önlisans, 369'u (\%41,3) lisans, 114'ü (\%12,8) lisansüstü eğitim düzeyinde olup, 249'u aylık (\%27,9) 5000 TL ve alt1, 300'ü $(\% 33,6)$ 5001-10000 TL, 195'i $(\% 21,8)$ 10001-15000 TL, 84'ü $(\% 9,4) 15001$-2000 TL, 66's1 $(\% 7,4) 20001 \mathrm{TL}$ ve aylık gelir düzeyinde olup, 183'ünün işletmesinin yıllık cirosu $(\% 20,5)$ $100.000 \mathrm{TL}$ ve altında, 129 'unun $(\% 14,4) 100.000$ - $250.000 \mathrm{TL}$ arasinda, 90'1nın $(\% 10,1) 251.000$ $500.000 \mathrm{TL}$ arasinda, 48'inin $(\% 5,4) 501.000$ - 750.000 TL arasinda 108'inin $(\% 12,1) 751.000$ 1000.000 TL arasında ve 336'sının (\%37,6) 1001.000 TL ve üzerindedir. 
İşletme sahiplerinin Kovid-19'un Ekonomik Faaliyetlerin Sürdürülebilirliğine Etkileri boyutundaki ifadelere verdiklerin yanıtların dağılımı Tablo 4'de verilmiştir.

Tablo 4: İşletme Sahiplerinin Kovid-19'un Ekonomik Faaliyetlerin Sürdürülebilirliğine Etkileri Boyutundaki İfadelere Verdiği Yanıtların Dağılımları

\begin{tabular}{lccc}
\hline İfadeler & Ort & Ss & Düzey \\
\hline İssyerimde Çalışan Sayısını Azaltmak Zorunda Kalacağımı & 3,782 & 1,107 & Yüksek \\
Düşünüyorum & 3,799 & 1,179 & Yüksek \\
Çek ve Senetlerimi Ödeyemeyeceğimi Düşünüyorum & 3,460 & 1,162 & Yüksek \\
Sunduğumuz Ürün ve Hizmetlere Eskisi Gibi Talep Olmayacağı & 3,493 & 1,350 & Yüksek \\
Kanaatindeyim & 3,926 & 1,174 & Yüksek \\
Evime ve Çocuklarıma Bakamamaktan Endişeliyim & 4,094 & 1,023 & Yüksek \\
Kredi ve Kredi Kartı Ödemelerinden Dolayı Bankalarla Sıkıntı & 3,758 & 1,236 & Yüksek \\
Yaşayacağımı Düşünüyorum & 3,829 & 1,079 & Yüksek \\
Önemli Düzeyde İş Kaybı Yaşayacağımı Düşünüyorum & 3,654 & 1,135 & Yüksek \\
İşyerimi Kapatmak Zorunda Kalmaktan Korkuyorum & 4,037 & 1,002 & Yüksek \\
Yeni Girişimcilik Faaliyetlerine Yönelemeyeceğimi Düşünüyorum & & \\
Alacaklarımı Tahsil Edemeyeceğimi Düşünüyorum & & & \\
Uygulanan Ekonomi Politikalarının Virüs Nedeniyle Gördüğüm Zararı & & \\
Gideremeyeceğini Düşünüyorum & & &
\end{tabular}

Tablo 4'teki verilere bakıldığında işletme sahiplerinin Kovid-19'un Ekonomik Faaliyetlerin Sürdürülebilirliğine Etkileri boyutunda yer alan ifadeler yüksek düzeyde katıldıkları, diğer bir ifade ile Kovid-19'un ekonomik faaliyetlerin sürdürülebilirliğine ilişkin yüksek düzeyde olumsuz görüşlere sahip oldukları belirlenmiştir.

İşletme sahiplerinin Kovid-19 Sürecinde Uygulanan Ekonomi Politikalarına Yönelik Görüşler boyutundaki ifadelere verdiklerin yanıtların dağılımı Tablo 5 'te verilmiştir.

Tablo 5: İşletme Sahiplerinin Kovid-19 Sürecinde Uygulanan Ekonomi Politikalarına Yönelik Görüşler Boyutundaki İfadelere Verdiği Yanıtların Dağılımları

\begin{tabular}{lccc}
\hline & Ort & Ss & Düzey \\
\hline Alınan Ekonomik Tedbirleri Yetersiz Buluyorum & 4,205 & 1,008 & Yüksek \\
Verilen Ekonomik Teşviklerin Yetersiz Kaldığını Düşünüyorum & 4,242 & 1,022 & Çok Yüksek \\
Gelecekle İlgili Ekonomik Endişelerim Var & 4,134 & 1,088 & Yüksek \\
Bu Dönemdeki Ekonomik Durgunluğun Gelecekte Ekonomik Açıdan & 4,040 & 1,102 & Yüksek \\
Sıkıntı Yaratacağını Düşünüyorum & 3,822 & 1,215 & Yüksek \\
Ekonomik Açıdan Kendimi Yetersiz Hissediyorum & 3,560 & 1,215 & Yüksek \\
Ekonominin Bundan Sonra Kolay Kolay Eski Hale Döneceğine & 4,037 & 1,125 & Yüksek \\
İnanmıyorum & &
\end{tabular}

Tablo 5'te yer alan Kovid-19 Sürecinde Uygulanan Ekonomi Politikalarına Yönelik Görüşler boyutundaki ifadelere işletme sahiplerinin katılım düzeylerine bakıldığında; "Verilen Ekonomik Teşviklerin Yetersiz Kaldığını Düşünüyorum" ifadesine çok yüksek düzeyde, diğer ifadelere ise yüksek düzeyde katıldıkları görülmektedir.

İşletme sahiplerinin Kovid-19 Sonrasına Yönelik Ekonomik Öngörüler boyutundaki ifadelere verdiklerin yanıtların dağılımı Tablo 6'da verilmiştir. 
Tablo 6: İşletme Sahiplerinin Kovid-19 Sonrasına Yönelik Ekonomik Öngörüler Boyutundaki İfadelere Verdiği Yanıtların Dağılımları

\begin{tabular}{lccc}
\hline & Ort & Ss & Düzey \\
\hline $\begin{array}{l}\text { Tüm Sektörlerin Ekonomik Açıdan Olumsuz Etkilendiğini } \\
\text { Düşünüyorum }\end{array}$ & 4,168 & 1,000 & Yüksek \\
$\begin{array}{l}\text { Rekabetin Daha Çok Olup Karlılıkların Azalacağını } \\
\text { Düşünüyorum }\end{array}$ & 3,738 & 1,065 & Yüksek \\
$\begin{array}{l}\text { Enflasyonun Ciddi Oranda Artacağını Düşünüyorum } \\
\text { Genel Ekonomiden Dijital Ekonomiye Hızlı Bir Geçiş }\end{array}$ & 4,020 & 1,030 & Yüksek \\
$\begin{array}{l}\text { Yaşanacağını Düşünüyorum } \\
\text { Küçük İşletmelerin Kapanma Riskiyle Karşı Karşıya }\end{array}$ & 3,624 & 1,043 & Yüksek \\
$\begin{array}{l}\text { Olduğunu Düşünüyorum } \\
\text { İşsizliğin Artacağını Düşünüyorum }\end{array}$ & 4,258 & 0,911 & Çok Yüksek \\
Ekonominin Canlanmasının Uzun Süre Alacağını & 4,312 & 0,909 & Çok Yüksek \\
Düşünüyorum & 4,117 & 1,045 & Yüksek \\
\hline
\end{tabular}

Tablo 6'da yer alan işletme sahiplerinin Kovid-19 Sonrasına Yönelik Ekonomik Öngörüler boyutunda yer alan ifadelerden "Küçük İşletmelerin Kapanma Riskiyle Karşı Karşıya Olduğunu Düşünüyorum" ve "İşsizliğin Artacağını Düşünüyorum" ifadelere çok yüksek düzeyde, diğer ifadelere ise yüksek düzeyde katıldıkları görülmektedir.

Tablo 7'de Kovid-19 Salgınının Ekonomi Üzerinde Etkileri ölçeğinde yer alan boyutların ortalamalarına yönelik veriler yer almaktadır.

Tablo 7: Kovid-19 Salgınının Ekonomi Üzerinde Etkileri Puan Ortalamaları

\begin{tabular}{lcccc}
\hline & N & Ort & Ss & Düzey \\
\hline $\begin{array}{l}\text { Kovid-19’un Ekonomik Faaliyetlerin Sürdürülebilirliğine } \\
\text { Etkileri }\end{array}$ & 894 & 3,783 & 0,891 & Yüksek \\
$\begin{array}{l}\text { Kovid-19 Sürecinde Uygulanan Ekonomi Politikalarına } \\
\text { Yönelik Görüsler }\end{array}$ & 894 & 4,006 & 0,865 & Yüksek \\
Kovid-19 Sonrasına Yönelik Ekonomik Öngörüler & 894 & 4,034 & 0,752 & Yüksek \\
Kovid-19 Salgınının Ekonomi Üzerinde Etkileri (Genel) & 894 & 3,921 & 0,779 & Yüksek \\
\hline
\end{tabular}

Tablo 7'deki verilere bakıldığında, “Kovid-19'un Ekonomik Faaliyetlerin Sürdürülebilirliğine Etkileri"ne yönelik görüşlerinin ortalaması 3,783 $\pm 0,891$, "Kovid-19 Sürecinde Uygulanan Ekonomi Politikalarına Yönelik Görüşler" ortalamasının 4,006 $\pm 0,865$, "Kovid-19 Sonrasına Yönelik Ekonomik Öngörüler" ortalamasının 4,034 $\pm 0,752$, "Kovid-19 Salgınının Ekonomi Üzerinde Etkilerinin (Genel)" ortalaması 3,921 $\pm 0,779$ olduğu saptanmıştır. Diğer bir ifade ile işletme sahipleri tüm boyutlardaki ifadelere yüksek düzeyde katılmaktadırlar.

Tablo 8'de araştırmaya katılan işletme sahiplerinin yaşlarına göre Kovid-19 salgınının ekonomi üzerinde etkilerine yönelik yapılan tek yönlü Anova testi verileri yer almaktadır. 
Tablo 8: Kovid-19 Salgınının Ekonomi Üzerinde Etkilerinin Katılımııların Yaşlarına Göre Farklilaşma Durumu

\begin{tabular}{|c|c|c|c|c|c|c|c|}
\hline & Grup & $\mathbf{N}$ & Ort & Ss & $\mathbf{F}$ & p & Fark \\
\hline \multirow{4}{*}{$\begin{array}{l}\text { Kovid-19'un Ekonomik } \\
\text { Faaliyetlerin Sürdürülebilirliğine } \\
\text { Etkileri }\end{array}$} & 1)20-30 & 66 & 4,309 & 0,563 & \multirow{4}{*}{9,244} & \multirow{4}{*}{$\mathbf{0 , 0 0 0}$} & \multirow{4}{*}{$\begin{array}{l}1>2 \\
1>3 \\
1>4\end{array}$} \\
\hline & 2) $31-40$ & 360 & 3,787 & 0,969 & & & \\
\hline & 3) $41-50$ & 366 & 3,691 & 0,901 & & & \\
\hline & 4)51-60 & 102 & 3,762 & 0,573 & & & \\
\hline \multirow{4}{*}{$\begin{array}{l}\text { Kovid-19 Sürecinde Uygulanan } \\
\text { Ekonomi Politikalarına Yönelik } \\
\text { Görüşler }\end{array}$} & 1)20-30 & 66 & 4,422 & 0,541 & \multirow{4}{*}{6,963} & \multirow{4}{*}{$\mathbf{0 , 0 0 0}$} & \\
\hline & 2)31-40 & 360 & 3,913 & 0,900 & & & \\
\hline & 3)41-50 & 366 & 3,998 & 0,898 & & & $\begin{array}{l}1>3 \\
1>4\end{array}$ \\
\hline & 4)51-60 & 102 & 4,092 & 0,695 & & & \\
\hline \multirow{4}{*}{$\begin{array}{l}\text { Kovid-19 Sonrasına Yönelik } \\
\text { Ekonomik Öngörüler }\end{array}$} & 1)20-30 & 66 & 4,331 & 0,482 & \multirow{4}{*}{5,071} & \multirow{4}{*}{$\mathbf{0 , 0 0 2}$} & \\
\hline & 2)31-40 & 360 & 4,069 & 0,792 & & & \\
\hline & 3)41-50 & 366 & 3,965 & 0,790 & & & \\
\hline & 4)51-60 & 102 & 3,966 & 0,528 & & & \\
\hline \multirow{4}{*}{$\begin{array}{l}\text { Kovid-19 Salgınının Ekonomi } \\
\text { Üzerinde Etkileri (Genel) }\end{array}$} & 1)20-30 & 66 & 4,349 & 0,450 & \multirow{4}{*}{7,566} & \multirow{4}{*}{$\mathbf{0 , 0 0 0}$} & \\
\hline & 2)31-40 & 360 & 3,906 & 0,836 & & & \\
\hline & 3)41-50 & 366 & 3,860 & 0,811 & & & \\
\hline & 4)51-60 & 102 & 3,918 & 0,497 & & & \\
\hline
\end{tabular}

Tablo 8'deki verilere bakıldığında Kovid-19 Salgınının Ekonomi Üzerinde Etkilerine yönelik tüm boyutlara ilişkin işletme sahiplerinin yaşlarına göre farklılaşma olduğu görülmektedir $(\mathrm{p}=0,000<0.05) .20-30$ yaş aralığındaki işletme sahiplerinin Kovid-19 salgınının ekonomi üzerinde etkilerine yönelik tüm boyutlarda görüşleri daha büyük yaşlardaki işletme sahiplerine göre daha olumsuzdur.

Tablo 9'da araştırmaya katılan işletme sahiplerinin cinsiyetlerine göre Kovid-19 salgınının ekonomi üzerinde etkilerine yönelik yapılan t- testi verileri yer almaktadır.

Tablo 9: Kovid-19 Salgınının Ekonomi Üzerinde Etkilerinin Katılımcıların Cinsiyetlerine Göre Farklılaşma Durumu

\begin{tabular}{lccccccc}
\hline & Grup & N & Ort & Ss & t & sd & p \\
\hline Kovid-19'un Ekonomik Faaliyetlerin & Kadın & 204 & 4,024 & 0,779 & \multirow{2}{*}{4,431} & \multirow{2}{*}{892} & $\mathbf{0 , 0 0 0}$ \\
Sürdürülebilirliğine Etkileri & Erkek & 690 & 3,712 & 0,910 & & & \\
Kovid-19 Sürecinde Uygulanan & Kadın & 204 & 4,296 & 0,745 & & & \\
Ekonomi Politikalarına Yönelik & Erkek & 690 & 3,920 & 0,880 & 5,550 & 892 & $\mathbf{0 , 0 0 0}$ \\
Görüssler & & & & & \\
Kovid-19 Sonrasına Yönelik Ekonomik & Kadın & 204 & 4,185 & 0,643 & \multirow{2}{*}{3,279} & 892 & $\mathbf{0 , 0 0 0}$ \\
Öngörüler & Erkek & 690 & 3,989 & 0,776 & & & \\
Kovid-19 Salgınının Ekonomi Üzerinde & Kadın & 204 & 4,150 & 0,669 & \multirow{2}{*}{4,833} & 892 & $\mathbf{0 , 0 0 0}$ \\
Etkileri (Genel) & Erkek & 690 & 3,854 & 0,797 & & & \\
\hline
\end{tabular}

Tablo 9'daki verilere göre kadın işletme sahiplerinin Kovid-19 salgınının ekonomi üzerinde etkilerine yönelik görüşleri erkek işletme sahiplerinin görüşlerinden daha olumsuzdur $(\mathrm{p}=0.000<0,05)$.

Tablo 10 'da araştırmaya katılan işletme sahiplerinin işletmelerinin faaliyet sürelerine göre Kovid-19 salgınının ekonomi üzerinde etkilerine yönelik yapılan tek yönlü Anova testi verileri yer almaktadir. 
Tablo 10: Kovid-19 Salgınının Ekonomi Üzerinde Etkilerinin Katılımcıların İşletmelerinin Faaliyet Süresine Göre Farklılaşma Durumu

\begin{tabular}{|c|c|c|c|c|c|c|c|}
\hline & Grup & $\mathbf{N}$ & Ort & Ss & $\mathbf{F}$ & $\mathbf{p}$ & Fark \\
\hline \multirow{5}{*}{$\begin{array}{l}\text { Kovid-19'un Ekonomik } \\
\text { Faaliyetlerin Sürdürülebilirliğine } \\
\text { Etkileri }\end{array}$} & 1)1-5 Y1l & 156 & 3,958 & 0,931 & \multirow{5}{*}{19,727} & \multirow{5}{*}{$\mathbf{0 , 0 0 0}$} & $1>4$ \\
\hline & 2)6-10 Y 11 & 231 & 3,978 & 0,826 & & & $2>4$ \\
\hline & 3)11-15 Y1l & 177 & 3,970 & 0,737 & & & $3>4$ \\
\hline & 4) $16-20 \mathrm{Y}_{11}$ & 177 & 3,575 & 0,909 & & & $1>5$ \\
\hline & $\begin{array}{l}\text { 5) } 21 \text { Y1l ve } \\
\text { Üzeri }\end{array}$ & 153 & 3,337 & 0,883 & & & $\begin{array}{l}3>5 \\
4>5\end{array}$ \\
\hline \multirow{5}{*}{$\begin{array}{l}\text { Kovid-19 Sürecinde Uygulanan } \\
\text { Ekonomi Politikalarına Yönelik } \\
\text { Görüşler }\end{array}$} & 1)1-5 Y1l & 156 & 4,124 & 0,813 & \multirow{5}{*}{16,126} & \multirow{5}{*}{$\mathbf{0 , 0 0 0}$} & $1>4$ \\
\hline & 2)6-10 Y1l & 231 & 4,134 & 0,722 & & & $2>4$ \\
\hline & 3)11-15 Yil & 177 & 4,230 & 0,731 & & & $3>4$ \\
\hline & 4)16-20 Y1l & 177 & 3,877 & 1,004 & & & $\begin{array}{l}1>5 \\
2>5\end{array}$ \\
\hline & $\begin{array}{l}\text { 5) } 21 \text { Y1l ve } \\
\text { Üzeri }\end{array}$ & 153 & 3,583 & 0,921 & & & $\begin{array}{l}3>5 \\
4>5\end{array}$ \\
\hline \multirow{5}{*}{$\begin{array}{l}\text { Kovid-19 Sonrasına Yönelik } \\
\text { Ekonomik Öngörüler }\end{array}$} & 1)1-5 Y1l & 156 & 4,140 & 0,728 & \multirow{5}{*}{16,447} & \multirow{5}{*}{$\mathbf{0 , 0 0 0}$} & $1>4$ \\
\hline & 2)6-10 Yil & 231 & 4,174 & 0,622 & & & $2>4$ \\
\hline & 3)11-15 Y1l & 177 & 4,230 & 0,677 & & & $3>4$ \\
\hline & 4)16-20 Y1l & 177 & 3,816 & 0,880 & & & $1>5$ \\
\hline & $\begin{array}{l}\text { 5)21 Y1l ve } \\
\text { Üzeri }\end{array}$ & 153 & 3,740 & 0,735 & & & $\begin{array}{l}2>5 \\
3>5\end{array}$ \\
\hline \multirow{5}{*}{$\begin{array}{l}\text { Kovid-19 Salgınının Ekonomi } \\
\text { Üzerinde Etkileri (Genel) }\end{array}$} & 1)1-5 Y1l & 156 & 4,059 & 0,782 & \multirow{5}{*}{20,636} & \multirow{5}{*}{$\mathbf{0 , 0 0 0}$} & $1>4$ \\
\hline & 2)6-10 Y 11 & 231 & 4,081 & 0,669 & & & $2>4$ \\
\hline & 3)11-15 Y1l & 177 & 4,122 & 0,666 & & & $3>4$ \\
\hline & 4)16-20 Y1l & 177 & 3,733 & 0,869 & & & $\begin{array}{l}1>5 \\
2>5\end{array}$ \\
\hline & $\begin{array}{l}\text { 5)21 Y1l ve } \\
\text { Üzeri }\end{array}$ & 153 & 3,526 & 0,759 & & & $\begin{array}{l}3>5 \\
4>5\end{array}$ \\
\hline
\end{tabular}

Tablo 10'daki verilere bakıldığında Kovid-19 Salgınının Ekonomi Üzerinde Etkilerine yönelik tüm boyutlara ilişkin işletme sahiplerinin faaliyet sürelerine göre farklılaşma olduğu görülmektedir ( $\mathrm{p}=0,000<0.05)$. $16-20$ y1l ve 21 y1l ve üzeri faaliyet gösteren işletme sahiplerinin Kovid-19 salgınının ekonomi üzerinde etkilerine yönelik tüm boyutlarda görüşleri faaliyet süresi daha az süre olan işletme sahiplerine göre daha olumludur.

Tablo 11'de araştırmaya katılan işletme sahiplerinin işletmelerinin hukuki statülerine göre Kovid-19 salgınının ekonomi üzerinde etkilerine yönelik yapılan tek yönlü Anova testi verileri yer almaktadir. 
Tablo 11: Kovid-19 Salgınının Ekonomi Üzerinde Etkilerinin Katılımcıların İşletmelerinin Hukuki Statüsü Göre Farklılaşma Durumu

\begin{tabular}{|c|c|c|c|c|c|c|}
\hline & Grup & $\mathbf{N}$ & Ort & Ss & $\mathbf{F}$ & $\mathbf{p}$ \\
\hline \multirow{4}{*}{$\begin{array}{l}\text { Kovid-19'un Ekonomik } \\
\text { Faaliyetlerin Sürdürülebilirliğine } \\
\text { Etkileri }\end{array}$} & 1)Şahıs İşletmesi & 426 & 3,780 & 0,995 & \multirow{4}{*}{1,375} & \multirow{4}{*}{0,249} \\
\hline & 2)Anonim Sirket & 42 & 3,521 & 0,776 & & \\
\hline & 3)Limited Şirket & 390 & 3,811 & 0,778 & & \\
\hline & 4)Diğer & 36 & 3,833 & 0,835 & & \\
\hline \multirow{4}{*}{$\begin{array}{l}\text { Kovid-19 Sürecinde Uygulanan } \\
\text { Ekonomi Politikalarına Yönelik } \\
\text { Görüşler }\end{array}$} & 1)Şahıs İşletmesi & 426 & 3,932 & 0,988 & \multirow{4}{*}{2,309} & \multirow{4}{*}{0,075} \\
\hline & 2)Anonim Şirket & 42 & 3,980 & 0,710 & & \\
\hline & 3)Limited Şirket & 390 & 4,075 & 0,740 & & \\
\hline & 4)Diğer & 36 & 4,167 & 0,634 & & \\
\hline \multirow{4}{*}{$\begin{array}{l}\text { Kovid-19 Sonrasına Yönelik } \\
\text { Ekonomik Öngörüler }\end{array}$} & 1)Şahıs İşletmesi & 426 & 4,019 & 0,842 & \multirow{4}{*}{0,821} & \multirow{4}{*}{0,482} \\
\hline & 2)Anonim Şirket & 42 & 3,929 & 0,651 & & \\
\hline & 3)Limited Şirket & 390 & 4,048 & 0,672 & & \\
\hline & 4)Diğer & 36 & 4,179 & 0,526 & & \\
\hline \multirow{4}{*}{$\begin{array}{l}\text { Kovid-19 Salgınının Ekonomi } \\
\text { Üzerinde Etkileri (Genel) }\end{array}$} & 1)Şahıs İşletmesi & 426 & 3,894 & 0,885 & \multirow{4}{*}{1,191} & \multirow{4}{*}{0,312} \\
\hline & 2)Anonim Şirket & 42 & 3,774 & 0,620 & & \\
\hline & 3)Limited Şirket & 390 & 3,957 & 0,677 & & \\
\hline & 4)Diğer & 36 & 4,031 & 0,617 & & \\
\hline
\end{tabular}

Tablo 11'deki verilere bakıldığında işletme sahiplerinin Kovid-19 salgınının ekonomi üzerinde Etkilerine yönelik tüm boyutlardaki görüşlerinin işletme statülerine göre anlamlı farklılık göstermemektedir ( $\mathrm{p}>0.05)$.

Tablo 12: Kovid-19 Salgınının Ekonomi Üzerinde Etkilerinin İşletmelerinin Aile İşletmesi Olma Durumuna Göre Göre Farklılaşma Durumu

\begin{tabular}{|c|c|c|c|c|c|c|c|}
\hline & Grup & $\mathbf{N}$ & Ort & Ss & $\mathbf{t}$ & sd & $\mathbf{p}$ \\
\hline \multirow{2}{*}{$\begin{array}{l}\text { Kovid-19'un Ekonomik } \\
\text { Faaliyetlerin Sürdürülebilirliğine } \\
\text { Etkileri }\end{array}$} & $\begin{array}{l}\text { Aile } \\
\text { İşletmesi }\end{array}$ & 375 & 3,717 & 0,950 & \multirow{2}{*}{$-1,898$} & \multirow{2}{*}{892} & \multirow{2}{*}{0,063} \\
\hline & Diğer & 519 & 3,831 & 0,843 & & & \\
\hline \multirow{2}{*}{$\begin{array}{l}\text { Kovid-19 Sürecinde Uygulanan } \\
\text { Ekonomi Politikalarına Yönelik } \\
\text { Görüşler }\end{array}$} & $\begin{array}{l}\text { Aile } \\
\text { İşletmesi }\end{array}$ & 375 & 3,953 & 0,873 & \multirow[t]{2}{*}{$-1,547$} & \multirow[t]{2}{*}{892} & \multirow[t]{2}{*}{0,122} \\
\hline & Diğger & 519 & 4,044 & 0,858 & & & \\
\hline \multirow{2}{*}{$\begin{array}{l}\text { Kovid-19 Sonrasına Yönelik } \\
\text { Ekonomik Öngörüler }\end{array}$} & $\begin{array}{l}\text { Aile } \\
\text { İşletmesi }\end{array}$ & 375 & 4,000 & 0,799 & \multirow[t]{2}{*}{$-1,151$} & \multirow[t]{2}{*}{892} & \multirow[t]{2}{*}{0,259} \\
\hline & Diğer & 519 & 4,059 & 0,716 & & & \\
\hline \multirow{2}{*}{$\begin{array}{l}\text { Kovid-19 Salgınının Ekonomi } \\
\text { Üzerinde Etkileri (Genel) }\end{array}$} & $\begin{array}{l}\text { Aile } \\
\text { İşletmesi }\end{array}$ & 375 & 3,868 & 0,815 & \multirow[t]{2}{*}{$-1,728$} & \multirow[t]{2}{*}{892} & \multirow[t]{2}{*}{0,088} \\
\hline & Diğer & 519 & 3,960 & 0,751 & & & \\
\hline
\end{tabular}

Tablo 12'deki verilere göre işletme sahiplerinin Kovid-19 salgınının ekonomi üzerinde etkilerine yönelik tüm boyutlardaki görüşlerinin işletmelerinin aile işletmesi olup olmadığına göre anlamlı farkl111k göstermemektedir(p>0.05).

Tablo 13'de araştırmaya katılan işletme sahiplerinin eğitim düzeylerine göre Kovid-19 salgınının ekonomi üzerinde etkilerine yönelik yapılan tek yönlü Anova testi verileri yer almaktadır. 
Tablo 13: Kovid-19 Salgınının Ekonomi Üzerinde Etkilerinin Katılımcıların Eğitim Düzeyine Göre Farklılaşma Durumu

\begin{tabular}{|c|c|c|c|c|c|c|c|}
\hline & Grup & $\mathbf{N}$ & Ort & Ss & $\mathbf{F}$ & $\mathbf{p}$ & Fark \\
\hline \multirow{4}{*}{$\begin{array}{l}\text { Kovid-19'un Ekonomik Faaliyetlerin } \\
\text { Sürdürülebilirliğine Etkileri }\end{array}$} & 1)Lise ve Alt1 & 327 & 3,738 & 0,962 & \multirow{4}{*}{4,901} & \multirow{4}{*}{0,002} & \multirow{4}{*}{$\begin{array}{l}3>1 \\
3>2 \\
3>4\end{array}$} \\
\hline & 2)Önlisans & 84 & 3,621 & 1,057 & & & \\
\hline & 3)Lisans & 369 & 3,909 & 0,765 & & & \\
\hline & 4)Lisansüstü & 114 & 3,626 & 0,879 & & & \\
\hline \multirow{4}{*}{$\begin{array}{l}\text { Kovid-19 Sürecinde Uygulanan Ekonomi } \\
\text { Politikalarına Yönelik Görüşler }\end{array}$} & 1)Lise ve Alt1 & 327 & 3,890 & 0,962 & \multirow{4}{*}{12,069} & \multirow{4}{*}{0,000} & \multirow{4}{*}{$\begin{array}{l}3>1 \\
3>2 \\
3>4\end{array}$} \\
\hline & 2)Önlisans & 84 & 3,709 & 0,945 & & & \\
\hline & 3)Lisans & 369 & 4,199 & 0,675 & & & \\
\hline & 4)Lisansüstü & 114 & 3,932 & 0,933 & & & \\
\hline \multirow{4}{*}{$\begin{array}{l}\text { Kovid-19 Sonrasına Yönelik Ekonomik } \\
\text { Öngörüler }\end{array}$} & 1)Lise ve Alt1 & 327 & 3,997 & 0,811 & \multirow{4}{*}{3,880} & \multirow{4}{*}{0,009} & \multirow{4}{*}{$\begin{array}{l}3>1 \\
3>2 \\
3>4\end{array}$} \\
\hline & 2)Önlisans & 84 & 3,867 & 0,821 & & & \\
\hline & 3)Lisans & 369 & 4,127 & 0,645 & & & \\
\hline & 4)Lisansüstü & 114 & 3,962 & 0,813 & & & \\
\hline \multirow{4}{*}{$\begin{array}{l}\text { Kovid-19 Salgınının Ekonomi Üzerinde } \\
\text { Etkileri (Genel) }\end{array}$} & 1)Lise ve Alt1 & 327 & 3,858 & 0,856 & \multirow{4}{*}{7,211} & \multirow{4}{*}{0,000} & \multirow{4}{*}{$\begin{array}{l}3>1 \\
3>2 \\
3>4\end{array}$} \\
\hline & 2)Önlisans & 84 & 3,719 & 0,887 & & & \\
\hline & 3)Lisans & 369 & 4,057 & 0,642 & & & \\
\hline & 4)Lisansüstü & 114 & 3,814 & 0,809 & & & \\
\hline
\end{tabular}

Tablo 13'teki verilere göre araştırmaya katılan ișletme sahiplerinin eğitim düzeylerine göre Kovid-19 Salgınının Ekonomi Üzerinde Etkilerine yönelik tüm boyutlara ilişkin görüşlerinde farklılaşma olduğu görülmektedir $(p=0,000<0.05)$. Lisans eğitim düzeyinde bulunan işletme sahipleri, diğer eğitim düzeyinde bulunanlara göre daha olumsuz görüşler içerisindedirler.

Tablo 14'de araştırmaya katılan işletme sahiplerinin yaşlarına göre Kovid-19 salgınının ekonomi üzerinde etkilerine yönelik yapılan tek yönlü Anova testi verileri yer almaktadır.

Tablo 14: Kovid-19 Salgınının Ekonomi Üzerinde Etkilerinin Katılımcıların Aylık Gelir Düzeylerine Göre Farklılaşma Durumu

\begin{tabular}{|c|c|c|c|c|c|c|c|}
\hline & Grup & $\mathbf{N}$ & Ort & Ss & $\mathbf{F}$ & $\mathbf{p}$ & Fark \\
\hline \multirow{5}{*}{$\begin{array}{l}\text { Kovid-19'un Ekonomik } \\
\text { Faaliyetlerin Sürdürülebilirliğine } \\
\text { Etkileri }\end{array}$} & 1)5000 TL ve Alt1 & 249 & 3,989 & 0,921 & \multirow{5}{*}{5,270} & \multirow{5}{*}{$\mathbf{0 , 0 0 0}$} & \multirow{5}{*}{$\begin{array}{l}1>2 \\
1>3 \\
1>4\end{array}$} \\
\hline & 2)5001-10000 TL & 300 & 3,688 & 0,889 & & & \\
\hline & 3) $10001-15000 \mathrm{TL}$ & 195 & 3,743 & 0,780 & & & \\
\hline & 4)15001 -2000 TL & 84 & 3,600 & 0,912 & & & \\
\hline & 5)20001 TL ve Üzeri & 66 & 3,791 & 0,949 & & & \\
\hline \multirow{5}{*}{$\begin{array}{l}\text { Kovid-19 Sürecinde Uygulanan } \\
\text { Ekonomi Politikalarına Yönelik } \\
\text { Görüşler }\end{array}$} & 1)5000 TL ve Altı & 249 & 4,152 & 0,824 & \multirow{5}{*}{3,510} & \multirow{5}{*}{0,007} & \multirow{5}{*}{$\begin{array}{l}1>2 \\
3>2 \\
1>4\end{array}$} \\
\hline & 2)5001-10000 TL & 300 & 3,897 & 0,914 & & & \\
\hline & 3)10001-15000 TL & 195 & 4,053 & 0,850 & & & \\
\hline & 4)15001 -2000 TL & 84 & 3,908 & 0,626 & & & \\
\hline & 5)20001 TL ve Üzeri & 66 & 3,935 & 1,013 & & & \\
\hline \multirow{5}{*}{$\begin{array}{l}\text { Kovid-19 Sonrasına Yönelik } \\
\text { Ekonomik Öngörüler }\end{array}$} & 1)5000 TL ve Altı & 249 & 4,098 & 0,766 & \multirow{10}{*}{4,126} & \multirow{5}{*}{$\mathbf{0 , 0 2 3}$} & \multirow{5}{*}{$\begin{array}{l}1>2 \\
5>2 \\
1>4 \\
5>4\end{array}$} \\
\hline & 2)5001-10000 TL & 300 & 3,954 & 0,793 & & & \\
\hline & 3)10001-15000 TL & 195 & 4,084 & 0,607 & & & \\
\hline & 4)15001 -2000 TL & 84 & 3,898 & 0,757 & & & \\
\hline & 5)20001 TL ve Üzeri & 66 & 4,182 & 0,841 & & & \\
\hline \multirow{5}{*}{$\begin{array}{l}\text { Kovid-19 Salgınının Ekonomi } \\
\text { Üzerinde Etkileri (Genel) }\end{array}$} & 1)5000 TL ve Altı & 249 & 4,068 & 0,794 & & & \multirow{5}{*}{$\begin{array}{l}1>2 \\
1>4\end{array}$} \\
\hline & 2)5001-10000 TL & 300 & 3,827 & 0,813 & & & \\
\hline & 3)10001-15000 TL & 195 & 3,933 & 0,667 & & 0,003 & \\
\hline & 4)15001 -2000 TL & 84 & 3,777 & 0,717 & & & \\
\hline & 5)20001 TL ve Üzeri & 66 & 3,947 & 0,872 & & & \\
\hline
\end{tabular}


Tablo 14'teki verilere göre araştırmaya katılan işletme sahiplerinin aylık gelir düzeylerine göre Kovid-19 salgınının ekonomi üzerinde etkilerine yönelik tüm boyutlara ilişkin görüşlerinde farklılaşma olduğu görülmektedir $(\mathrm{p}=0,000<0.05)$. Genel olarak aylık $5000 \mathrm{TL}$ ve altında gelire sahip olanlar, Kovid-19 salgınının ekonomi üzerindeki etkilerine dair daha olumsuz görüş içerisindedirler.

Tablo 15'de araştırmaya katılan işletme sahiplerinin yaşlarına göre Kovid-19 salgınının ekonomi üzerinde etkilerine yönelik yapılan tek yönlü Anova testi verileri yer almaktadır.

Tablo 15: Kovid-19 Salgınının Ekonomi Üzerinde Etkilerinin Katılımcıların İşletmelerinin Yııllık Cirosuna Göre Farklılaşma Durumu

\begin{tabular}{|c|c|c|c|c|c|c|c|}
\hline & Grup & $\mathbf{N}$ & Ort & Ss & $\mathbf{F}$ & $\mathbf{p}$ & Fark \\
\hline \multirow{6}{*}{$\begin{array}{l}\text { Kovid-19'un Ekonomik Faaliyetlerin } \\
\text { Sürdürülebilirliğine Etkileri }\end{array}$} & 1) $100.000 \mathrm{TL}$ ve Alt1 & 183 & 4,218 & 0,792 & \multirow{6}{*}{12,344} & \multirow{6}{*}{0,000} & \multirow{2}{*}{$\begin{array}{l}1>2 \\
1>2\end{array}$} \\
\hline & 2) $100.000-250.000 \mathrm{TL}$ & 129 & 3,749 & 0,690 & & & \\
\hline & 3)251.000 - $500.000 \mathrm{TL}$ & 90 & 3,700 & 1,012 & & & $1>3$ \\
\hline & 4)501.000 - $750.000 \mathrm{TL}$ & 48 & 3,538 & 0,851 & & & $\begin{array}{l}1>4 \\
1>5\end{array}$ \\
\hline & 5)751.000 - $1000.000 \mathrm{TL}$ & 108 & 3,731 & 0,937 & & & $1>3$ \\
\hline & 6)1001.000 TL ve Üzeri & 336 & 3,634 & 0,895 & & & \\
\hline \multirow{6}{*}{$\begin{array}{l}\text { Kovid-19 Sürecinde Uygulanan } \\
\text { Ekonomi Politikalarına Yönelik } \\
\text { Görüşler }\end{array}$} & 1) $100.000 \mathrm{TL}$ ve Alt1 & 183 & 4,255 & 0,809 & \multirow{6}{*}{5,716} & \multirow{6}{*}{0,000} & \\
\hline & 2) $100.000-250.000 \mathrm{TL}$ & 129 & 3,821 & 0,857 & & & $1>2$ \\
\hline & 3) $251.000-500.000 \mathrm{TL}$ & 90 & 3,814 & 0,948 & & & $5>2$ \\
\hline & 4) $501.000-750.000 \mathrm{TL}$ & 48 & 4,009 & 0,867 & & & $1>3$ \\
\hline & $5) 751.000-1000.000 \mathrm{TL}$ & 108 & 4,103 & 0,797 & & & $5>3$ \\
\hline & 6)1001.000 TL ve Üzeri & 336 & 3,961 & 0,865 & & & \\
\hline \multirow{6}{*}{$\begin{array}{l}\text { Kovid-19 Sonrasına Yönelik } \\
\text { Ekonomik Öngörüler }\end{array}$} & 1) $100.000 \mathrm{TL}$ ve Altı & 183 & 4,237 & 0,680 & \multirow{6}{*}{3,621} & \multirow{6}{*}{0,003} & \\
\hline & 2) $100.000-250.000 \mathrm{TL}$ & 129 & 3,983 & 0,681 & & & $1>2$ \\
\hline & 3)251.000 - $500.000 \mathrm{TL}$ & 90 & 4,000 & 0,847 & & & $1>3$ \\
\hline & 4)501.000 - $750.000 \mathrm{TL}$ & 48 & 3,982 & 0,824 & & & $\begin{array}{l}1>4 \\
1>5\end{array}$ \\
\hline & 5)751.000 - $1000.000 \mathrm{TL}$ & 108 & 4,044 & 0,622 & & & $\begin{array}{l}1>5 \\
1>6\end{array}$ \\
\hline & 6)1001.000 TL ve Üzeri & 336 & 3,957 & 0,800 & & & \\
\hline \multirow{6}{*}{$\begin{array}{l}\text { Kovid-19 Salgınının Ekonomi } \\
\text { Üzerinde Etkileri (Genel) }\end{array}$} & 1) $100.000 \mathrm{TL}$ ve Alt1 & 183 & 4,234 & 0,723 & \multirow{6}{*}{8,084} & \multirow{6}{*}{0,000} & \\
\hline & 2) $100.000-250.000 \mathrm{TL}$ & 129 & 3,838 & 0,665 & & & $1>2$ \\
\hline & 3)251.000 - $500.000 \mathrm{TL}$ & 90 & 3,821 & 0,888 & & & $1>3$ \\
\hline & 4)501.000 - $750.000 \mathrm{TL}$ & 48 & 3,805 & 0,789 & & & $1>4$ \\
\hline & 5)751.000 - $1000.000 \mathrm{TL}$ & 108 & 3,931 & 0,742 & & & $\begin{array}{l}1>5 \\
1>6\end{array}$ \\
\hline & 6)1001.000 TL ve Üzeri & 336 & 3,823 & 0,790 & & & \\
\hline
\end{tabular}

Tablo 15 'teki verilere göre araştırmaya katılan işletme sahiplerinin yıllık cirolarına göre Kovid-19 salgınının ekonomi üzerinde etkilerine yönelik tüm boyutlara ilişkin görüşlerinde farklılaşma olduğu görülmektedir $(\mathrm{p}=0,000<0.05)$. Tüm boyutlarda yıllık cirosu $100.000 \mathrm{TL}$ ve altında olanlar Kovid-19 salgınının ekonomi üzerindeki etkilerine dair daha olumsuz görüş içerisindedirler.

\section{Sonuç ve Öneriler}

Yeni tip koronavirüs olarak da bilinen Kovid-19, 2019 yılı sonunda Çin'de ortaya çıkmış, sonrasında dünya ülkelerine yayılarak 11 Mart’ta Türkiye'de ilk vaka görülmüştür. Ortaya çıktığı günden itibaren bulaştığı kişi sayısı ve virüsten ölenlerin sayısı her geçen gün artış göstermektedir.

Virüsün yayılma hızının düşürülmesine yönelik ekonomik ve sosyal hayatı kısıtlandırıcı bir dizi önlemler alınmıştır. Alınan bu önlemler içerisinde, işletme sahiplerinin bulunduğu sektöre göre; faaliyetlerinin sınırlandırmasından faaliyetlerinin durdurulmasına kadar gidilmiştir. Sosyal ve ekonomik yaşam durağanlaşmış, bu durum işletme sahiplerinin ekonomiye ilişkin gelecek 
kaygılarını artırmıştır. Hükümetler vatandaşların bu endişelerinin giderilmesine yönelik ekonomik paketler açıklayarak yürürlüğe koymuşlardır. Kovid-19 salgını nedeniyle ortaya çıkan ekonomik belirsizliği gidermeye yönelik ülkelerin birbirine benzer tarafları ve farklılıkları olan farklı büyüklüklerde ekonomik paketler açıkladıkları görülmüştür. Almanya'nın salgınla mücadelede en kapsamlı ekonomik paketi (GSYH'sinin yaklaşık \%22'sini kapsayan) açıkladı̆̆ 1 izlenirken, Almanya'yı GSYH'sinin \%10,3'ü ile ABD'nin \%10 ile Polonya'nın takip ettiği görülmektedir. Türkiye'nin salgınla mücadele için açıkladığı ekonomik paket, GSYH'sinin \%2'sine tekabül etmektedir.

$\mathrm{Bu}$ araştırmada Kovid-19 salgınının ekonomi üzerinde ne gibi etkilerinin olabileceğine yönelik işletme sahiplerinin görüşlerinin incelenmesi amaçlanmıştır. Bu doğrultuda 894 işletme sahibinin görüşü incelenmiştir.

İşletme sahiplerinin görüşleri "Kovid-19'un Ekonomik Faaliyetlerin Sürdürülebilirliğine Etkileri”, "Kovid-19 Sürecinde Uygulanan Ekonomi Politikalarına Yönelik Görüşler”, "Kovid-19 Sonrasına Yönelik Ekonomik Öngörüler" olmak üzere üç boyutta ayrıca bu üç boyutun toplamını ifade eden "Kovid-19 Salgınının Ekonomi Üzerinde Etkileri (Genel)" olarak incelenmiştir. İşletme sahiplerinin ölçekteki tüm boyutlara katılımları yüksek düzeyde olmuştur. Diğer bir ifade ölçek boyutlarının içerdiği olumsuz ifadeler gözönüne alındığında işletme sahipleri Kovid-19 sonrası ekonomik faaliyetlerini sürdürebilme konusunda ciddi endişeler içerisinde olup, bu süreçte uygulanan ekonomi politikalarını yetersiz olarak değerlendirmektedirler. Ayrıca Kovid-19 sonrasında da ekonomi açısından önemli endişeler taşımaktadırlar.

İşletme sahiplerinin ön plana çıkan görüşleri şunlardır: "Verilen Ekonomik Teşviklerin Yetersiz Kaldığını Düşünüyorum”, "Küçük İşletmelerin Kapanma Riskiyle Karşı Karşıya Olduğunu Düşünüyorum" ve "İşsizliğin Artacağını Düşünüyorum”. Görüşlerden de anlaşılacağı üzere işletme sahipleri ekonomik teşviklerin yetersiz olduğunu düşünmekte, Kovid-19 sonrası birçok küçük işletmenin kapanacağı ve işsizliğin artacağı öngörüsündedirler.

Araştırmada işletme sahiplerinin Kovid-19 salgınının ekonomi üzerindeki etkilerine yönelik görüşlerinin tanımlayıcı özelliklerine göre farklılık gösterip göstermediği de incelenmiştir. $\mathrm{Bu}$ doğrultuda ele alınan ilk değişken olarak katılımcıların yaşlarına göre Kovid-19 salgınının ekonomi üzerindeki etkilerine yönelik görüşlerinin farklılık gösterdiği, 20-30 yaş aralığındaki katılımcıların daha büyük yaşlardaki katılımcılara göre daha olumsuz görüşler içerisinde oldukları saptanmıştır. Genç yaştaki katılımcıların ekonomik olumsuzluklarla ve bu tür kriz durumlarıyla daha az karşılaşmalarının bu görüşlerinde etkili olabileceği düşünülmektedir.

Katılımcıların cinsiyetlerine göre Kovid-19 salgınının ekonomi üzerindeki etkilerine yönelik görüşlerinde farklılaşmaların olduğu, tüm boyutlarda kadın işletme sahiplerinin erkeklere göre daha olumsuz düşünceler içerisinde oldukları belirlenmiştir. Kadınların duygusal yapılarının bu süreçte etkili olduğu düşünülmektedir.

Bir diğer farklılaşma katılımcıların faaliyet sürelerinde görülmüştür. 16 y1lın üzerinde faaliyet gösteren işletme sahiplerinin Kovid-19 salgınının ekonomi üzerindeki etkilerine yönelik görüşlerinin daha az faaliyet süresi olanlara göre daha olumlu olduğu saptanmıştır. Yıllara sahip tecrübenin olaylara bakış açısında daha sakin ve objektif bakmaya neden olduğu söylenebilir.

Araştırmada katılımcıların işletmelerinin hukuksal statüsünün ve aile işletmesi olmasının Kovid-19 salgınının ekonomi üzerindeki etkilerine yönelik görüşlerinde farklılaşmaya neden olmadığ belirlenmiştir. Diğer bir ifade ile farklı statülerde işletmesi bulunan aile işletmesi sahibi olan veya olmayan işletme sahiplerinin Kovid-19 salgınının ekonomi üzerindeki etkilerine yönelik görüşleri birbirine benzerlik göstermektedir.

Araştırmaya katılan işletme sahiplerinin eğitim düzeylerine göre Kovid-19 salgınının ekonomi üzerindeki etkilerine yönelik görüşlerinin farklılık gösterdiği belirlenmiştir. Lisans eğitim 
düzeyinde bulunan işletme sahiplerinin diğer eğitim düzeyinde bulunan işletme sahiplerine göre daha olumsuz görüşler içerisinde oldukları belirlenmiştir.

Katılımcıların aylık gelir düzeylerine göre de Kovid-19 salgınının ekonomi üzerindeki etkilerine yönelik görüşlerinin farklılık gösterdiği saptanmıştır. Aylık gelir düzeyi $5000 \mathrm{TL}$ ve altında olanların Kovid-19 salgınının ekonomi üzerindeki etkilerine yönelik görüşlerinin daha yüksek gelir düzeyindekilere göre daha olumsuz olduğu belirlenmiştir. Diğer bir ifade ile düşük gelir düzeyindekilerin ekonomik endişeleri daha fazladır. Benzer bir sonuçta işletme sahiplerinin yıllık cirolarına göre de Kovid-19 salgınının ekonomi üzerindeki etkilerine yönelik görüşlerinde farklılıklar olmasıdır. Yıllık ciroları 100.000 TL ve altında olanların, yıllık cirosu daha yüksek düzeyde olan işletme sahiplerine göre Kovid-19 salgınının ekonomi üzerindeki etkilerine yönelik görüşlerinin daha olumsuz olduğu, başka bir ifade ile ekonomik endişelerinin daha yoğun olduğu sonucuna ulaşılmıştır. Buradan hükümetin 5000 TL'den daha düşük gelire sahip ve yıllık 100.000'TL'den düşük ciroya sahip olan işletme sahiplerine yönelik yapılan teşvikleri artırması veya ekonomik faaliyetlerini sürdürebilir kılmaya yönelik yeni teşvikleri yürürlüğe koyması önerilmektedir.

Sonuç olarak işletme sahiplerinin yüksek düzeyde Kovid-19'un ekonomiyi olumsuz etkileyeceği görüşünde olup, gelecek açısından önemli endișeler taşıdıkları saptanmıștır. Bu sonucun ortaya çıkmasında Kovid-19 gibi bir salgın türüyle ilk defa karşılaşan işletme sahiplerinin belirsizlik ortamında panik havasına kapılarak yoğun endişe içerisine girdikleri düşünülmektedir.

$\mathrm{Bu}$ dönemde yapılması gereken en önemli şey, işletmeleri ve bankaları iflastan kurtarmak için alınacak mali önlemlerdir, böylece pandemi bittiğinde hızlı bir şekilde iyileşme sürecine girilebilir. Politika yapıcılar, firmaların gerektiğinde borç almasına yardımcı olmak için çeşitli vergi indirimi ve kamu garantilerini dikkate almalıdır. Ancak en umut verici seçenek kısa süreli çalışma ödeneğidir. Çalışma ödeneği sayesinde işgücü sigortası için mevcut kullanılan kanallar aracıllğıyla işgücünün eksik istihdamı telafi edilebilmektedir. Daha da iyisi, neredeyse hiçbir maliyeti yoktur, çünkü artan gerçek işsizlikten kaynaklanan kayıpları önlenebilecektir. Türkiye'de bu önlemleri almış ve uygulamaya koymuştur.

Bu doğrultuda Türkiye Kovid-19'a karşı kamuda ve sosyal yaşamda eyleme geçirilecek birçok yeni önlem almıştır. Bu bağlamda Türkiye'de hastane yoğun bakım üniteleri genişletilmiş; geçici hastaneler inşa edilmiş, solunum maskeleri, koruyucu giysiler ve koruyucu maskeler seri olarak üretilmiş ve ihtiyaç duyan herkesin kullanımına sunulmuştur. Bunun ötesinde, halk sağlı̆̆ 1 otoritelerine fabrikaları ve diğer kamusal alanları dezenfekte etmek için ihtiyaç duydukları kaynak ve fonlar tahsis edilmiştir. Hijyen Kovid-19 salgınıyla mücadelede en önemli önceliktir. Türkiye'deki hükümetin de bu yönde uygulamalar yaptığı gözlenmektedir.

Kovid-19'la mücadelede; zamanında ve etkili önlem alan ülkelerin başarılı oldukları gözlenmiştir. Yeni Zelanda erken uygula - sıkı uygula politikasıyla, Güney Kore tekil vakaların izlenmesi yoluyla, Vietnam tespit, takip ve tecrit yoluyla, Ürdün erken ve sistematik eylemlerle, Gana virüsün coğrafi ayak izini anlamaya çalışarak, Venezüella ekonomik kriz şartlarında Güney Amerika'nın en başarılı mücadelesini vererek Kovid-19'la mücadele etmiştir. Sözü edilen bu ülkeler coğrafi konum itibariyle daha yalıtılmış ve nispeten kontrol edilebilir ölçekteki nüfusları sebebiyle de daha avantajlı duruma sahip olmuşlardır. Türkiye, bu örnekler içerisinde salgını önlemeye yönelik tedbirleri erken almış, Sağlık Bakanlığı hızlı tarama sistemini kontrollü bir şekilde yürüterek, erken tanılama ve önleyici, tedavi edici uygulamalarıyla, salgınla mücadelesini başarılı ve görece az can kaybıyla yürütmeye çalışmaktadır.

Sürecin iyi yönetilmesi ve gerekli ekonomi politikalarının yürürlüğe girmesiyle ve salgının sona ermesiyle birlikte, belirsizlik ortamının kalkacağı ve işletme sahiplerinin yaşadıkları panik durumumun son bularak daha olumlu görüşler ve beklentiler içerisine girecekleri öngörülmektedir. 
Çalışma sırasında yapılan literatür taraması ve kendi çalışma sonuçlarımız doğrultusunda; salgının faaliyetleri kısıtlanan tüm sektörleri ekonomi genelinde olumsuz bir sonuca götürdügünü, şirketlerin henüz net stratejilerle hareket edemediklerini, kimi zaman bu salgının cirolarında artışa sebep olacağını düşünürken, kimi zaman da bu salgını kendilerine firsat olarak gördükleri belirlenmiştir. $\mathrm{Bu}$ doğrultuda işverenlerin çalışanları için yönergeler hazırladığı, vergi indirimleri, kredi ve mali yardım, ithalat ve ihracat eksikliklerinin karşılanması konusunda, devlet desteği ve yönlendirmesinin gerekliliği üzerinde yaşanan iktisadi sorunlar temelinde virüsün yayılmaması için alınan önlemlerin önemli olduğu görülmüştür. Bu süreçte salgının aniden birçok iktisadi faaliyet alanını daralttığı ve tedarik zincirlerine zarar vererek sadece Türkiye'nin değil küresel düzeyde bir iktisadi krize sürüklediği ve bunun sonucunda ülkelerin yeni iktisat politikaları uygulayarak krizden en fazla etkilendiklerini düşündükleri alanlarda, sektör ve topluma yönelik devlet destek programları başlattıkları görülmektedir. Salgın koşullarının yarattığı bu olumsuz iktisadi yapıya en uygun, en sağlıklı iktisat politikası uygulayan ülkelerin iktisadi problemleri daha da kolay aşacakları umulmaktadır.

\section{Kaynakça}

Anadolu Ajansı (18.03.2020). Hükümet 100 milyar liralık 'Ekonomik İstikrar Kalkanı' paketini açıladı,https://www.aa.com.tr/tr/info/infografik/17798

Ayittey, F.K., Ayittey, M. K., Chiwero, N. B., Kamasah, J. S., \& Dzuvor, C. (2020). Economic impacts of Wuhan 2019-nCoV on China and the world. Journal of Medical Virology, 10.1002/jmv.25706. https://onlinelibrary.wiley.com/doi/epdf/10.1002/jmv.25706 Erişim tarihi: 06.03.2020

Buruk, K., \& Özlü, T. (2020). Yeni koronavirus: SARS-CoV-2. Mucoso, 3 (1), 1-14

EY (30.03.2020). Hükümetlerin büyük sinavl: 19 Ülkede Covid-19 destek paketleri. Ankara: Türkiye Kamu Sektörü Danışmanlık Hizmetleri.

Karacaer-Ulusoy, M. (2020). Economic Effects of Corona Virus on Turkey's Economy. https://www.sde.org.tr/analysis/economic-effects-of-corona-virus-on-turkeys-economyanalizi-16163 Erişim tarihi: 31.03.2020

Karasar, N. (2012). Bilimsel araştırma yöntemi. Ankara: Nobel Yayın Dağıtım.

Karcığlu Ö (2020). Coronavirüs nedir, nas1l korunabiliriz? Phnx Med J.. 2(1), 66-71.

Kılıç, S. (2016). Cronbach'ın alfa güvenirlik katsayısı. Journal of Mood Disorders, 6 (1), 47-48.

Kıran, A. (2020). 2020 Küresel Korona Virüsü Krizi. https://kiranjournal.com/2020/04/01/2020kuresel-korona-virusu-krizi/ Erişim tarihi: 01.04.2020.

Mahase, E. (2020). Coronavirus: global stocks of protective gear aredepleted, with demand at "100 times" normal level, WHO warns. BMJ, 368: m543 doi: 10.1136/bmj.m543 https://www.bmj.com/content/bmj/368/bmj.m543.full.pdf. Erişim tarihi: 10.02.2020.

Örneklem Hesaplama (2020). https://www.anketcozumu.com/orneklem-hesaplama/ Erişim tarihi: 31.03.2020.

Reddy, S. G. (2020). Coronavirus and The Limits of Economics. https://foreignpolicy.com/2020/03/31/coronavirus-pandemic-rethinking-economics/ Erişim tarihi: 31.03.2020

Sağlık Bakanlığı (2020) Covid-19 Rehberi, (25.02.2020). Halk Sağlığı Genel Müdürlüğü, Covid-19 (2019-n CoV Hastalığı) Rehberi (Bilim Kurulu Çalışması). Sağlık Bakanlığı. 
SETA, 5 Soru: Almanya Koronavirüs ile Nasıl Mücadele Ediyor? https://www.setav.org/5-sorualmanya-koronavirus-ile-nasil-mucadele-ediyor/ Erişim tarihi: 31.03 .2020

Sinn, H.W. (2020). How Best to Fight The Economic Impact of The Coronavirus Pandemic, https://www.theguardian.com/business/2020/mar/17/how-best-to-fight-the-economic-impactof-the-coronavirus-pandemic Erişim tarihi: 31.03.2020

Smit, S., Hirt, M., Buehler, K.., Lund, S., Greenberg, E., \& Govindarajan, A. (2020). We Must Solve for The Virus and The Economy. It Starts With Battling The Virus https://www.mckinsey.com/business-functions/strategy-and-corporate-finance/ourinsights/safeguarding-our-lives-and-our-livelihoods-the-imperative-of-our-time Erişim tarihi : 31.03. 2020.

Sözcü Gazetesi (14.03.2020). https://www.sozcu.com.tr/2020/gundem/son-dakika-corona-virususon-yillarin-en-buyuk-saglik-krizine-karsi-turkiye-ne-yapti-5679069/

T.C. Sağlık Bakanlığ1, https://covid19.saglik.gov.tr/ Erişim tarihi: 31.03.2020

Taymaz E. (2020). Covid-19 Tedbirlerinin Ekonomik Etkileri ve Politika Önerileri. https://sarkac.org/2020/03/covid-19-tedbirlerinin-ekonomik-etkileri-ve-politika-onerileri/ Erişim tarihi: 24.03 .2020

TC. Sağlık Bakanlığı (2019). Pandemic Infulenza Ulusal Hazırlık Planı. Ankara: Halk Sağlığı Genel Müdürlügü Türkiye Ekonomi Politikaları Araştırma Vakfı [TEPAV]. İstihdam İzleme Bülteni, (85), 1-21.

UNWTO Impact Assessment of the Covid-19 Outbreak on International Tourism (2020) https://webunwto.s3.eu-west-1.amazonaws.com/s3fs-public/2020-03/UNWTO-ImpactAssessment-COVID19.pdf Erişim tarihi: 10.03.2020.

World Health Organization (2020). Coronavirus (Covid-19) https://who.sprinklr.com Erişim tarihi: 31.03.2020

Yeniçağ Gazetesi (18.032020). https://www.yenicaggazetesi.com.tr/erdogandan-korona-zirvesisonrasi-aciklama-272214h.htm 